\title{
Metamorphic evolution of the Loma Marcelo skarn within the geotectonic context of the crystalline basement of the Ventania System (Argentina)
}

\author{
Carlos A. Ballivián Justiniano ${ }^{\mathrm{a}}$, María F. Lajoinie ${ }^{\mathrm{a}}$, Clemente Recio ${ }^{\mathrm{b}}$, Ana M. Sato ${ }^{\mathrm{c}}$, \\ Miguel A.S. Basei ${ }^{\mathrm{d}}$, Joaquín A. Proenza ${ }^{\mathrm{e}}$, Thomas H. Aiglsperger ${ }^{\mathrm{e}, 1}$, Raúl E. de Barrio ${ }^{\mathrm{f}}$,
} Marcela V. Curci ${ }^{\mathrm{f}}$, Mabel E. Lanfranchini ${ }^{\mathrm{g}, *}$

\footnotetext{
${ }^{a}$ Consejo Nacional de Investigaciones Científicas y Técnicas (CONICET). Instituto de Recursos Minerales (INREMI), Universidad Nacional de La Plata-Comisión de Investigaciones Científicas de la Provincia de Buenos Aires, Calle 64 esquina 120, 1er piso, C.P. 1900, La Plata, Argentina

bepartamento de Geología, Facultad de Ciencias, Universidad de Salamanca (USAL), Plaza de los Caídos s/n, 37008, Salamanca, Spain

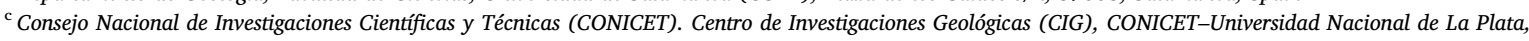
Diagonal $113 N^{\circ}$ 275, C.P. B1904DPK, La Plata, Argentina

${ }^{\mathrm{d}}$ Centro de Pesquisas Geocronológicas (CPGeo), Instituto de Geociências, Universidade de São Paulo, Cidade Universitária, Rua do Lago 562, CEP 05508-080, São Paulo (SP), Brazil

${ }^{\mathrm{e}}$ Departament de Mineralogia, Petrologia i Geologia Aplicada, Facultat de Ciències de la Terra, Universitat de Barcelona (UB), Martí i Franquès s/n, 08028, Barcelona, Spain ${ }^{\mathrm{f}}$ Instituto de Recursos Minerales (INREMI), Universidad Nacional de La Plata-Comisión de Investigaciones Científicas de la Provincia de Buenos Aires, Calle 64 esquina 120, 1er piso, C.P. 1900, La Plata, Argentina

${ }^{\mathrm{g}}$ Comisión de Investigaciones Científicas de la Provincia de Buenos Aires (CIC). Instituto de Recursos Minerales (INREMI), Universidad Nacional de La Plata-CIC, Calle 64 esquina 120, 1er piso, C.P. 1900, La Plata, Argentina
}

\section{A R T I C L E I N F O}

\section{Keywords:}

Carbonate xenoliths

Mineral chemistry

LA-ICP-MS U-Pb

Stable isotopes

Hydrothermal fluids

Sierras Australes of Buenos Aires Province

\begin{abstract}
A B S T R A C T
This study describes the mineralogical and isotopic changes that carbonate xenoliths experienced under multiple metamorphic events and hydrothermal fluid circulation during the evolution of the Ventania System basement. The high reactivity of carbonate xenoliths allowed the preservation of mineral assemblages corresponding to at least three metamorphic events in the resulting Loma Marcelo skarn. The Ventania System basement is composed of Neoproterozoic granites and ignimbrites, Early Cambrian granites, and Middle Cambrian rhyolites. Carbonate xenoliths were incorporated during the intrusion of a calc-alkaline granite with an LA-ICP-MS U-Pb crystallization age of $621.6 \pm 2.2 \mathrm{Ma}$. The intrusion induced pyroxene-hornfels facies metamorphism in the carbonate xenoliths and the associated metasomatism generated calcic and magnesian skarns depending on the protolith composition. Garnet, clinopyroxene, wollastonite, bytownite, and meionite were formed in the calcic skarn (CaS), whereas forsterite and spinel were formed in the magnesian skarn (MgS). Crystallization of Early Cambrian alkaline granites was accompanied by intense hydrothermal activity that was responsible for low temperature $\left(\leq 300{ }^{\circ} \mathrm{C}\right)$ F-metasomatism in the skarn, as evidenced by the presence of F-rich vesuvianite ( $\mathrm{CaS}$ ) and chondrodite ( $\mathrm{MgS}$ ), among other minerals. Vesuvianite was formed from calc-silicate mineral assemblages of the previous metamorphic event, whereas chondrodite was formed by replacement of forsterite. The low temperature formation of these typical high-grade minerals could be an evidence of mineral formation under disequilibrium conditions favoured by the high reactivity of hydrothermal fluids. Neopalaeozoic basement mylonitization under greenschist facies metamorphism was accompanied by hydrothermal fluid circulation. This event promoted extreme mobility of chemical elements in the basement rocks and epidotization $(\mathrm{CaS})$ and serpentinization $(\mathrm{MgS})$ in the Loma Marcelo skarn. The elongated and boudinaged shape of the skarn bodies, parallel to the mylonitic foliation, is a consequence of dextral shearing that affected the basement rocks. Additionally, almost pure grossular crystallized post-tectonically in the CaS. Carbonates of the Loma Marcelo skarn are depleted in ${ }^{13} \mathrm{C}$ and ${ }^{18} \mathrm{O}\left(\delta^{13} \mathrm{C}_{\mathrm{V}-\mathrm{PDB}}=-2.5 /-10.1 \%\right.$; $\delta^{18} \mathrm{O}_{\mathrm{V} \text {-SMow }}=+7.3 /+14.0 \%$ o $)$ relative to carbonate sedimentary rocks. The $\delta^{13} \mathrm{C}$ and $\delta^{18} \mathrm{O}$ variations can be attributed to the interaction between large amounts of hydrothermal fluids $(\mathrm{W} / \mathrm{R}=30-50)$ and Neoproterozoic carbonate sedimentary rocks.
\end{abstract}

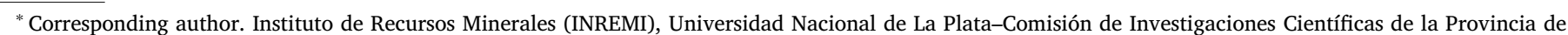
Buenos Aires, Calle 64 esquina 120, 1er piso, C.P. 1900, La Plata, Argentina.

E-mail address: lanfranchini@yahoo.com (M.E. Lanfranchini).

${ }^{1}$ Present address: Department of Civil Engineering and Natural Resources, Division of Geosciences and Environmental Engineering, Luleå University of Technology. SE 97187 Luleå, Sweden. 


\section{Introduction}

The identification and interpretation of mineral assemblages in metacarbonate rocks are important means of determining the evolution of a metamorphic terrane. Carbonate rocks, and their metamorphic equivalents, are ubiquitous and strongly reactive. They respond quickly to any kind of fluid influx. Thus, carbonate rocks have been used to constrain metamorphic conditions in areas composed of unreactive rocks, such as granites and rhyolites, whose metamorphic equivalents are not particularly useful indicators of metamorphic grade (e.g., Bucher and Grapes, 2011).

In the Neoproterozoic basement of the Ventania System, located in southwestern Buenos Aires Province, Argentina (Fig. 1a and b), Kilmurray (1968a, 1975) described some skarn outcrops with calc-silicate and magnesian mineral assemblages hosted in a calc-alkaline granite that has undergone low-grade mylonitization (von Gosen et al., 1990; Rapela et al., 2003). These skarn outcrops were collectively referred to as Loma Marcelo skarn (Ballivián Justiniano et al., 2015).

Skarns are rocks formed by the interaction of carbonate and silicate systems in mutual contact (Zharikov et al., 2011) during regional, dynamic, or contact metamorphism through metasomatic processes involving fluids of magmatic, metamorphic, meteoric, and/or marine origin (Meinert et al., 2005). They are formed from carbonate protoliths of diverse nature, like limestones, dolostones, marls, hydrothermal carbonates, carbonatites, and marbles. What defines a rock as skarn is the mineralogy resulting from metasomatic alteration, which includes numerous calc-silicate or magnesian minerals, depending on the chemical composition of the protolith (Einaudi et al., 1981; Meinert, 1992).

Petrographical, geochemical, and geochronological data suggested that the Loma Marcelo skarn was formed from carbonate xenoliths incorporated during the intrusion of the granite that hosts the skarn (Ballivián Justiniano et al., 2017). The sedimentary nature of the carbonate protoliths is reflected in the chemical and mineralogical composition of the resulting skarn. The Loma Marcelo skarn protoliths had calcic and magnesian compositions, which determined the generation of calc-silicate and magnesian mineral assemblages, respectively. The former correspond to a calcic skarn mainly composed of grossular-andradite, diopside-hedenbergite, wollastonite, vesuvianite, and calcite, whereas the latter correspond to a magnesian skarn mainly composed of forsterite, spinel, chondrodite, dolomite, and calcite. The Loma Marcelo skarn is evidence of the occurrence of carbonate sedimentary rocks in the underground of the Ventania System. The skarn protoliths would be genetically related to the Neoproterozoic carbonate sedimentation recorded in Eastern South America and Western Africa on tectonically stable cratons, in basins around the stable cratons, and in basins associated with tectonically active fold belts (Misi et al., 2007 and references therein).

The aim of this work is to study the mineralogical and isotopic changes experienced by the Loma Marcelo skarn during metamorphic and metasomatic processes, due to variables such as protolith composition and water/rock ratio, among others. We also present new geochronological LA-ICP-MS U-Pb zircon dating for the granite that hosts the Loma Marcelo skarn, which allows the minimum sedimentation age of the skarn protoliths to be constrained. The Loma Marcelo skarn has preserved in its mineralogy and chemistry evidence of the processes that affected the crystalline basement of the Ventania System, which reveals the importance of fluids during its evolution.

\section{Regional geological setting}

The Ventania System is a mountain chain comprised of a Neoproterozoic-Middle Cambrian crystalline basement and a Late Cambrian-Early Permian sedimentary cover (Fig. 1b). The basement crops out scarcely in the western sector of the system and is composed of Tonian granites, Ediacaran granites and ignimbrites, Early Cambrian granites, Middle Cambrian rhyolites, a dike-like andesitic body, and the
Loma Marcelo skarn (Kilmurray, 1961, 1968a, 1968b; Rapela et al., 2003; Tohver et al., 2012; Ballivián Justiniano et al., 2015, 2017, under review).

The Ventania System basement was attributed to the Brasiliano/ Pan-African Orogenic Cycle (e.g., Varela and Cingolani, 1976). Based on lithogeochemical, geochronological, and isotopic data, Rapela et al. (2003) related the Ediacaran magmatism to the closure of the Adamastor Ocean due to the collision between the Río de la Plata and the Kalahari cratons, the Early Cambrian magmatism to an extensional event, and the Middle Cambrian magmatism to a mantle thermal anomaly. Recently, Ballivián Justiniano et al. (under review) highlighted that the tectonic evolution of the Ventania System basement is consistent with that observed in the Dom Feliciano Belt and its African counterparts, namely the Kaoko, Damara, Gariep, and Saldania belts. These authors also pointed out that zircon cores from the Neoproterozoic igneous rocks of the Ventania System have U-Pb inherited ages between $c a .1200$ and $c a .900$ Ma that could be indicating a lineage with the Gariep Belt and its Namaqua basement in southwestern Africa.

The Tonian magmatism of the Ventania System would be related to the break-up of the Rodinia Supercontinent and subsequent opening of the Adamastor Ocean (Ballivián Justiniano et al., under review). Rocks of this age can also be found in the Dom Feliciano Belt, both in the Cerro Olivo Complex of the Punta del Este Terrane (e.g., Basei et al., 2011; Lenz et al., 2011) and in basement inliers of the Pelotas Batholith (e.g., Koester et al., 2016). The Ediacaran magmatism of the Dom Feliciano Belt and the Ventania System would be related to the subduction of the Adamastor Ocean to the east (in today's coordinates), generating a magmatic arc along the western margin of the Congo-Kalahari cratons (Basei et al., 2018; Ballivián Justiniano et al., under review). The final closure of the Adamastor Ocean and the collision between the Río de la Plata-Paranapanema and Congo-Kalahari cratons would have occurred during the Ediacaran ( $\sim 600 \mathrm{Ma})$ and would have been followed by a post-collisional magmatism developed due to orogenic collapse. The opening of the South Atlantic Ocean during the Cretaceous along the back-arc basin of the Brasiliano/Pan-African orogenic belt, left in South America a large part of the magmatic arc (the Granite Belt of the Dom Feliciano Belt), as well as the Punta del Este Terrane and the Ventania System basement (Basei et al., 2018; Ballivián Justiniano et al., under review).

Harrington (1947) included the Palaeozoic cover of the Ventania System in the Curamalal (Late Cambrian-Ordovician), Ventana (Silurian-Devonian), and Pillahuincó (Late Carboniferous-Early Permian) groups (Fig. 1b). It is composed of siliciclastic sedimentary rocks deposited in stable platform, glacimarine, and fluvio-deltaic environments (Andreis et al., 1989). The Middle Cambrian rhyolites (ca. 509 Ma; Rapela et al., 2003) are the youngest basement rocks known in the Ventania System, which allow constraining the maximum sedimentation age of the Palaeozoic cover to the Middle/Late Cambrian. On the other hand, $\mathrm{U}-\mathrm{Pb}$ zircon dating of tuffs interbedded in the upper half of the top unit of the Pillahuincó Group (Tunas Formation) yielded ages of ca. 292-281 Ma (Tohver et al., 2008; Alessandretti et al., 2013; LópezGamundí et al., 2013; Arzadún et al., 2018), which allow the age of the Palaeozoic cover to be extended at least until the Early Permian.

The crystalline basement and the Palaeozoic sedimentary cover of the Ventania System were deformed and metamorphosed together. Metamorphic conditions were bracketed between the greenschist facies and the anchizone (von Gosen et al., 1990, 1991). The most remarkable structural characteristic of the Ventania System are the folds of the Palaeozoic cover. In the western sector of the system, folds are overturned and the axial planes mostly verge to the NE. The intensity of folding and metamorphic degree decrease towards the northeastern sector of the system (von Gosen et al., 1990, 1991). Thrust faults with a $\mathrm{NE}$ vergence both affected the basement and the Palaeozoic cover, promoting the imbrication of tectonic slices in the same direction (e.g., Schiller, 1930; Kilmurray, 1975; Cobbold et al., 1991; Tomezzoli and Cristallini, 1998, 2004). 


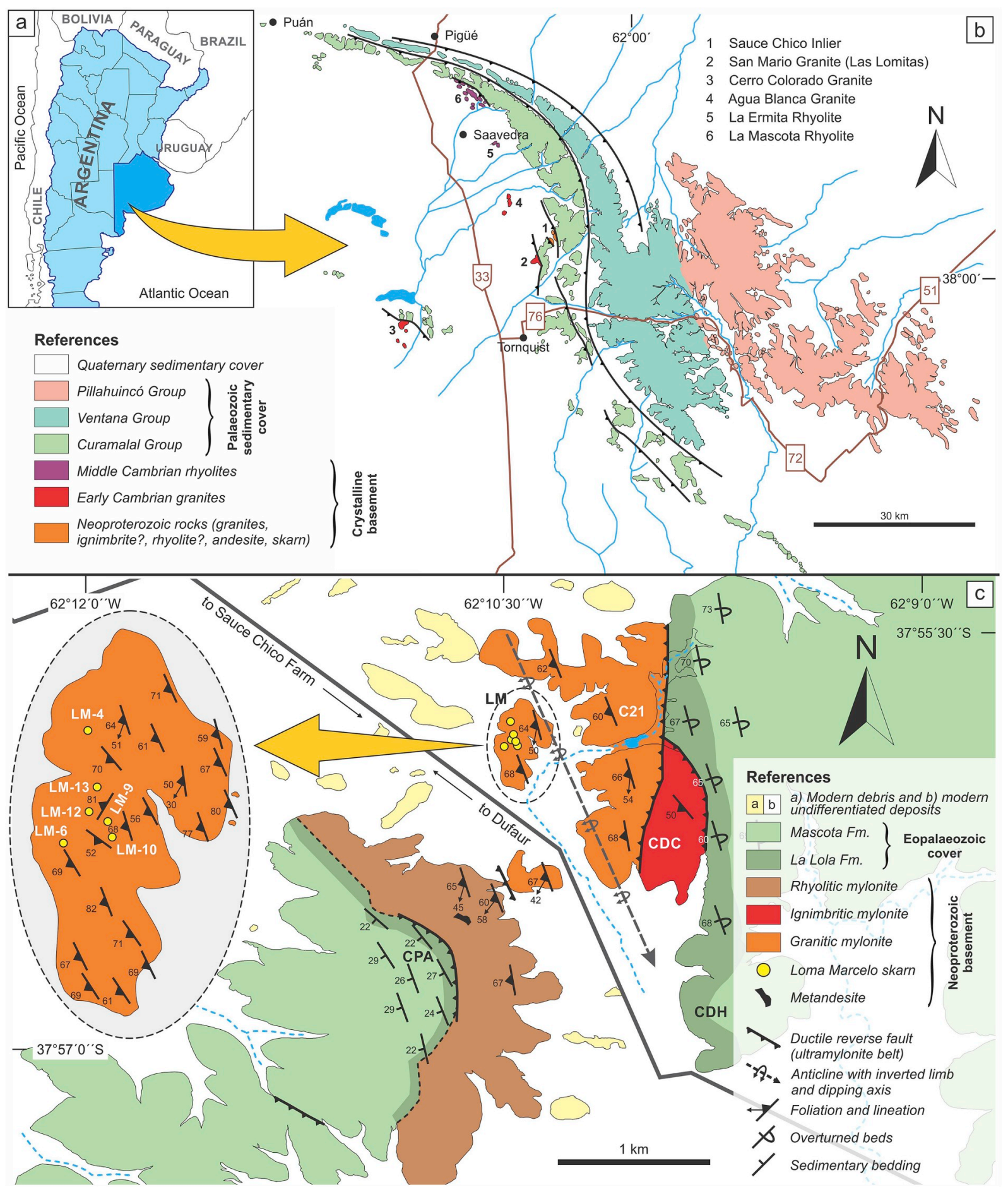

Fig. 1. a) Political map of Argentina, indicating the location of the Buenos Aires Province and the Ventania System. b) Geological map of the Ventania System (modified from Ramos et al., 2014). c) Geological map of the Sauce Chico Inlier (1 in part b; modified from Ballivián Justiniano et al., 2017). Abbreviations: CPA = Cerro Pan de Azúcar, CDC = Cerro del Corral, $\mathrm{C} 21$ = Cerro 21 de Septiembre, LM = Loma Marcelo, CDH = Cerro del Hueco.

K-Ar dating of illites from the Curamalal Group allows the deformation age to be assigned to the Permian (ca. 282-257 Ma; Varela et al., 1985; Buggisch, 1987). Further palaeomagnetic studies revealed that the lower part of the Tunas Formation was deposited, deformed, and magnetized during the Early Permian (Tomezzoli, 1999, 2001; Tomezzoli and Vilas, 1999). Isotopic dating conducted by Ballivián Justiniano et al. (2017) yielded ages of $364.4 \pm 3.6 \mathrm{Ma}$ (Rb-Sr quartz-sericite isochron from a vein that cut mylonites) and $353.4 \pm 6.7 \mathrm{Ma}$ (LA-ICP-MS U-Pb dating of zircons from the Loma
Marcelo skarn), suggesting the existence of a pre-Permian deformation event.

\section{Local geological setting of the crystalline basement}

\subsection{Sauce Chico Inlier}

The Cerro Pan de Azúcar-Cerro del Corral is the study area. Basement rocks are mylonitized and belong to the Sauce Chico Group 
(Cuerda et al., 1975). The basement underlies the sedimentary rocks of the La Lola (conglomerate) and Mascota (quartzite) formations of the Curamalal Group (Fig. 1c). The area is an erosive window called Sauce Chico Inlier (Ballivián Justiniano et al., 2017), where Cerro Pan de Azúcar and Cerro del Corral represent the southwestern and northeastern flanks, respectively, of a faulted overturned anticline. The NW-SE to N-S trending mylonitic foliation dips $30-90^{\circ}$ to the SW/W (Ballivián Justiniano et al., 2017) (Fig. 1c). The associated stretching lineation dips between 42 and $47^{\circ}$ to the SSW, whereas the kinematic indicators reveal dextral shearing with a top-to-NNE hanging wall. Mylonitization promoted mobility of chemical elements, including rareearth elements (Grecco et al., 2000). Deformation and metamorphism would have reached pressures of about $200 \mathrm{MPa}$ and temperatures between 350 and $400{ }^{\circ} \mathrm{C}$ (Delpino and Dimieri, 1992; Ballivián Justiniano et al., 2017).

Mylonitic granites were formed from monzogranitic and syenogranitic protoliths with equigranular and porphyritic textures (Figs. 1c and 2a). They are mainly composed of quartz, microcline, albite-oligoclase, and biotite and/or muscovite. The mylonitic matrix is mainly composed of sericite, with lesser amounts of chlorite, biotite, quartz, and feldspar (Fig. 2b). Garnet, magnetite, apatite, zircon, epidote, and/ or calcite are present as accessory minerals.

Mylonitic granites (sensu lato) show a broad silica range (57.0-80.5\% $\mathrm{SiO}_{2}$ ), high $\mathrm{K}_{2} \mathrm{O}$ content $\left(2.7-11.2 \% \mathrm{~K}_{2} \mathrm{O}\right.$ ), and calc-alkaline and peraluminous characteristics (Grecco et al., 2000; Rapela et al., 2003; Gregori et al., 2005; Ballivián Justiniano et al., 2017, under review). The lanthanides (rare-earth elements, REE) content is highly variable (49.9-539.2 ppm). These rocks fall within the volcanic arc, syn-collisional, and I\&S-type fields of the tectonic discrimination diagrams. U-Pb zircon dating of granitic rocks from the Sauce Chico Inlier yielded ages of $784.9 \pm 4.4$ Ma for the Loma Meyer Granite (Ballivián Justiniano et al., under review), ca. 621 Ma for the Cerro 21 de Septiembre and Loma Marcelo granites (Ballivián Justiniano et al., under review), and 607.0 $\pm 5.2 \mathrm{Ma}$ for the Cerro del Corral Granite (Rapela et al., 2003). Additionally, Ballivián Justiniano et al. (under review) obtained an U-Pb zircon age of $775.9 \pm 6.7 \mathrm{Ma}$ in an orthogneiss xenolith hosted in the Loma Marcelo Granite. This last granite also hosts metasomatised carbonate xenoliths referred to as Loma Marcelo skarn (Ballivián Justiniano et al., 2017).
The Loma Marcelo skarn protoliths had calcic and magnesian compositions, which determined the generation of calc-silicate (calcic skarn) and magnesian (magnesian skarn) mineral assemblages. The calcic skarn crops out in the central-western sector of Loma Marcelo and is mainly composed of grossular-andradite, diopside-hedenbergite, wollastonite, vesuvianite, and calcite. The outcrops are aligned in a NNW-SSE trend along $175 \mathrm{~m}$ (Fig. 1c). The contact between the mylonitic granite and the calcic skarn is well defined and concordant with the mylonitic foliation. It was only observed along the western boundary of LM-9 (Fig. 1c), a NW-SE elongated outcrop $10 \mathrm{~m}$ long and $5 \mathrm{~m}$ wide. In LM-9, both mylonitic granite and skarn exhibit penetrative foliation. The foliation of the mylonitic granite adapts to the lenticular shape of the skarn outcrop. The magnesian skarn crops out in the western sector of Loma Marcelo (LM-6 in Fig. 1c) and is mainly composed of forsterite, spinel, chondrodite, dolomite, and calcite. The only identified outcrop is $2.8 \mathrm{~m}$ long and $2.2 \mathrm{~m}$ wide.

A mylonitic ignimbrite of phenorhyolitic to phenodacitic composition (González et al., 2004) and alkaline geochemical characteristics (Ballivián Justiniano et al., under review) crops out at Cerro del Corral (Fig. 1c). This unit was classified as rhyolite and rhyolitic porphyry by other authors (e.g., Kilmurray, 1961, 1968a, 1968b, 1975; Delpino, 1993; Rapela et al., 2003; Gregori et al., 2005). The ignimbrite outcrop is bounded by two N-S trending and W dipping ultramylonite belts. They juxtaposed the ignimbrite in tectonic contact with granitic mylonites to the west and with La Lola Formation to the east (Fig. 1c). The ignimbrite has porphyritic texture with quartz and feldspar crystalloclasts of 3-4 $\mathrm{mm}$ in length immersed in a reddish-brown to greenishgrey aphanitic matrix (Fig. 2c). The fiammes that define the eutaxitic texture are crushed and compacted and have lenticular shape. Varela et al. (1990) recalculated the Rb-Sr whole-rock results obtained by Varela and Cingolani (1976) for the Cerro del Corral Ignimbrite, obtaining an isochron age of $678 \pm 30 \mathrm{Ma}$. The U-Pb zircon dating of the Cerro del Corral Ignimbrite yielded a crystallization age of $582.6 \pm 4.5$ Ma (Ballivián Justiniano et al., under review).

A mylonitic rhyolite of phenodacitic to phenorhyolitic composition crops out at the NE slope of Cerro Pan de Azúcar (Fig. 1c). In this hill, Kilmurray (1975) pointed out the presence of fine grain mylonites possibly derived from porphyry, welded tuffs, or rhyolites, whereas Gregori et al. (2005) recognized rocks of volcanic nature, which they
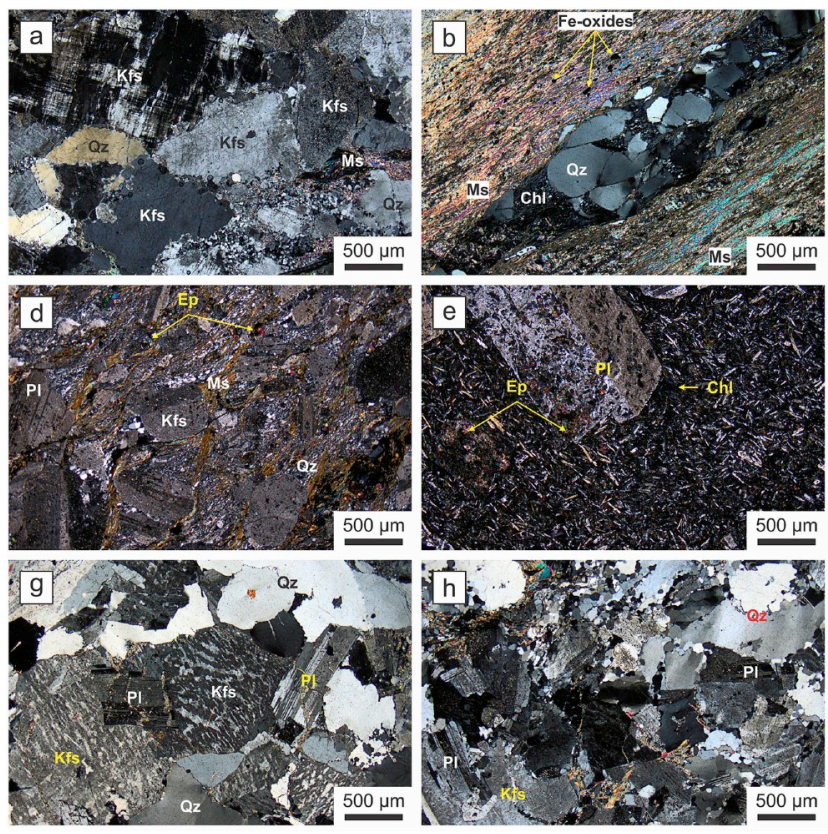
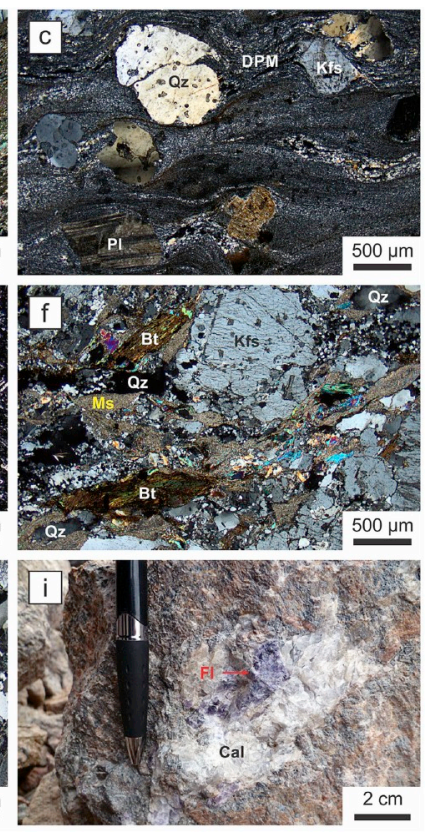

Fig. 2. a) Loma Marcelo Granite (not mylonitized): granular texture, with interstitial muscovite and quartz mosaics with granoblastic texture (crossed Nicols view). b) Loma Marcelo Granite (mylonitized): ribbon composed of quartz and chlorite; the mylonitic matrix is mainly composed of muscovite and Fe-oxide appears as scattered grains throughout the mylonitic matrix (crossed Nicols view). c) Cerro del Corral Ignimbrite: crystalloclasts (now porphyroclasts) of quartz and feldspar surrounded by the devitrified pyroclastic matrix (DPM; crossed Nicols view). d) Cerro Pan de Azúcar Rhyolite: crystalloclasts (now porphyroclasts) of feldspar with interstitial muscovite and quartz mosaics with granoblastic texture (crossed Nicols view). e) Cerro Pan de Azúcar Andesite: phenocryst of plagioclase immersed in an aphanitic groundmass with pilotaxitic texture and development of epidote and chlorite (crossed Nicols view). $\mathbf{f}$, g, h) Granular texture in the San Mario (f), Agua Blanca (g), and Cerro Colorado (h) granites (crossed Nicols view). i) Outcrop of the Cerro Colorado Granite showing a nodule of fluorite and calcite. Abbreviations: $\mathrm{Bt}=$ biotite, Cal = calcite,$\quad \mathrm{Chl}=$ chlorite,$\quad \mathrm{Ep}=$ epidote, $\mathrm{Fl}=$ fluorite, $\mathrm{Kfs}=\mathrm{K}$-feldspar, $\mathrm{Ms}=$ muscovite, $\mathrm{Pl}=$ plagioclase, $\mathrm{Qz}=$ quartz. 
classified as rhyolites. The rhyolite outcrop is bounded by two N-S to NNW-SSE trending and W/WSW dipping ultramylonite belts. They juxtaposed the rhyolite in tectonic contact with granitic mylonites at the foot of the hill and with La Lola Formation to the top of the hill (Fig. 1c). The rhyolite has porphyritic texture with quartz and feldspar phenocrysts generally smaller than $6 \mathrm{~mm}$ in length immersed in a pale grey aphanitic matrix (Fig. 2d). Elongate domains devitrified into spherulitic and clean quartzo-feldspathic aggregates are interpreted as fiammes. These fiamme-like domains allow interpreting the Cerro Pan de Azúcar Rhyolite as another ignimbritic outcrop. Unlike the Cerro del Corral Ignimbrite, the Cerro Pan de Azúcar Rhyolite (or Ignimbrite) has calc-alkaline geochemical characteristics (Ballivián Justiniano et al., under review). The U-Pb zircon dating of the Cerro Pan de Azúcar Rhyolite yielded a crystallization age of $542.8 \pm 4.2$ Ma (Ballivián Justiniano et al., under review).

The Cerro Pan de Azúcar Rhyolite hosts small fragments of granite and andesite and a dyke-like andesitic body $80 \mathrm{~m}$ long and $30 \mathrm{~m}$ wide (Fig. 1c). The andesitic body has porphyritic texture with large phenocrysts of plagioclase $\left(\mathrm{An}_{5-20}\right)$ up to $4 \mathrm{~cm}$ in length (Fig. 2e). Like its host rock, the andesite is deformed and foliated. The andesitic body also contains chlorite, epidote, and actinolite as metamorphic mineral assemblage. Gregori et al. (2005) and Ballivián Justiniano et al. (under review) classified the Cerro Pan de Azúcar Andesite as a calc-alkaline volcanic rock. The last authors suggested a Cambrian age for the dykelike andesitic body.

\subsection{Other basement rocks close to the Sauce Chico Inlier}

The San Mario Granite is a biotite monzogranite with equigranular texture that crops out about $4 \mathrm{~km}$ southwest of the Sauce Chico Inlier (Figs. 1b and 2f). It is limited by a NNW-SSE trending and WSW dipping ultramylonite belt that juxtaposed the granite in tectonic contact with La Lola Formation to the east (e.g., Cobbold et al., 1991). The San Mario Granite has an U-Pb zircon age of $524.3 \pm 5.3 \mathrm{Ma}$ and I-type geochemical characteristics (Rapela et al., 2003).

The Agua Blanca Granite is a fluorite-bearing monzogranite with equigranular texture that crops out about $11 \mathrm{~km}$ northwest of the Sauce Chico Inlier (Figs. $1 \mathrm{~b}$ and $2 \mathrm{~g}$ ), in a small abandoned quarry, and is unconformable covered by tosca and soils. Although the granite is infertile in zircons (Rapela et al., 2003) and its age of magmatic crystallization is not known, it probably correlates with the Cerro Colorado Granite because it shares the same petrographic and geochemical characteristics (Fig. 2h and i). The Cerro Colorado Granite crops out in the plain that extends west of the Ventania System (Fig. 1b), about $30 \mathrm{~km}$ WNW of the Sauce Chico Inlier, and has an U-Pb zircon age of $531.1 \pm 4.1 \mathrm{Ma}$ and A-type geochemical characteristics (Rapela et al., 2003).

\section{Materials and methods}

Mineralogical and textural studies of the Loma Marcelo skarn were conducted using polarized optical and scanning electron microscopes and X-ray diffraction by the powder method (XRD). Electron microprobe (EMP) analyses were performed with a JEOL Superprobe JXA8230 microprobe at the Serveis Científics $i$ Tecnòlogics (SCiT; Universitat de Barcelona, Spain) and the Laboratorio de Microscopía Electrónica y Análisis por Rayos X (LAMARX; Universidad Nacional de Córdoba, Argentina). A CAMECA Camebax SX-100 microprobe of the Geology Department of the Universidad de Oviedo (Spain) was also used. Crystals of garnet, clinopyroxene, wollastonite, vesuvianite, forsterite, chondrodite, spinel, dozyite, and carbonates from the Loma Marcelo skarn were analysed using current acceleration of $15 \mathrm{kV}$, electric current of $10-20 \mathrm{nA}$, and a beam diameter of $1-2 \mu \mathrm{m}$. Calibrations were performed using natural and synthetic standards. End-member proportions of garnet, clinopyroxene, forsterite, and spinel were calculated based on the obtained results following the method of Deer et al. (1992). The Fe was reported as total $\mathrm{FeO}$. In the case of garnet, clinopyroxene, vesuvianite, and spinel, $\mathrm{Fe}^{3+}$ was stoichiometrically calculated according to Droop (1987). The OH content of the hydrated minerals was also stoichiometrically calculated. Appendix A includes an extensive chemical database of the different mineral phases studied in this work. The mineral abbreviations used in this work are those of Whitney and Evans (2010).

One sample of the Loma Marcelo Granite (19198), that hosts the homonymous skarn, was selected for LA-ICP-MS U-Pb zircon dating. Concentration and separation of zircon grains were done at the Centro de Investigaciones Geológicas (CIG, CONICET-UNLP) and the Instituto de Recursos Minerales (INREMI, UNLP-CIC). A sample of $6.5 \mathrm{~kg}$ was crushed, washed, milled, and sieved. The heavy minerals were concentrated with a pan. Zircon grains were handpicked in alcohol under a binocular microscope. Prior to LA-ICP-MS U-Pb analyses, the selected zircon grains were mounted in epoxy resin and their internal structure exposed by polishing for cathodoluminescence imagery and U-Pb dating. The $\mathrm{U}-\mathrm{Pb}$ ages were obtained at the Centro de Pesquisas Geocronológicas (CPGeo) of the Universidade de São Paulo (Brazil) with a Thermo-Fisher Neptune LA-ICP-MS equipped with a 193 Photon laser system, following the analytical method described by Sato et al. (2010). The results were plotted with Isoplot 4.15 (Ludwig, 2008) and are provided in Appendix B.

Carbon and oxygen stable isotope determinations in carbonates were performed at the Servicio General de Análisis de Isótopos Estables of the Universidad de Salamanca (Spain). The analysed minerals were handpicked under a binocular microscope. The extraction of $\mathrm{CO}_{2}$ from calcite and dolomite from the Loma Marcelo skarn for isotopic analysis was performed by reacting with $103 \% \mathrm{H}_{3} \mathrm{PO}_{4}$ at $25{ }^{\circ} \mathrm{C}$ during $3 \mathrm{~h}$ for calcite and $72 \mathrm{~h}$ for dolomite (McCrea, 1950; Craig, 1957). Isotope ratios were measured with a VG-Isotech SIRA-II dual inlet mass spectrometer. Both internal and international reference standards were run to check accuracy and precision. Results were reported in $\delta(\%)$ notation relative to the Vienna Standard Mean Ocean Water (V-SMOW) for $\delta^{18} \mathrm{O}$ and Vienna Peedee Belemnite (V-PDB) for $\delta^{13} \mathrm{C}$. Long-term reproducibility for repeated determination of reference samples was better than $\pm 0.2 \%$ o $(1 \sigma)$.

\section{Petrography and mineral chemistry}

\subsection{The Loma Marcelo Granite}

The Loma Marcelo Granite is a mylonitic syenogranite with abundant micaceous minerals (sericite), scarce porphyroclasts of feldspar (microcline and oligoclase), C- and C'-type shear bands, and well-developed foliation. Quartz ribbons and quartz mosaics with polygonal granoblastic texture are frequent (Fig. 2b). It was possible to identify the syenogranitic protolith as sectors preserved from mylonitization and as porphyroclasts included in the mylonitic matrix. In both cases, the syenogranitic protolith has equigranular texture and medium to coarse grain size (Fig. 2a) (cataclastic granite of Ballivián Justiniano et al., 2017). Lithogeochemical information of the Loma Marcelo Granite can be found in Ballivián Justiniano et al. (2017, under review). This granite hosts several outcrops of the homonymous skarn (Fig. 1c).

\subsection{The Loma Marcelo skarn}

The Loma Marcelo skarn was distinguished in calcic and magnesian skarns based on its chemical and mineralogical composition. The terms calcic and magnesian are usually used to describe the dominant composition of the protolith and the resulting skarn minerals (e.g., Meinert et al., 2005).

\subsubsection{Calcic skarn (calc-silicate assemblages)}

The calcic skarn exhibits variable colour and grain size (Fig. 3) and is composed of two well defined mineral paragenesis including three 


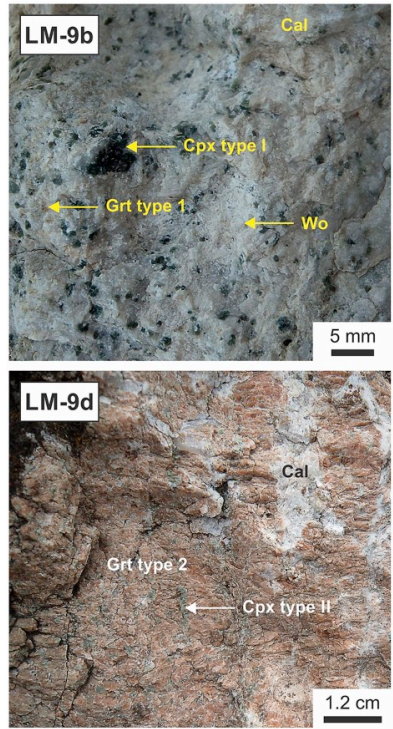

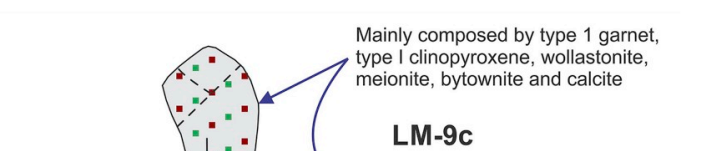

LM-9a
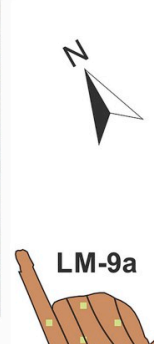

types of garnet (1,2, and 3), two types of clinopyroxene (I and II), wollastonite, scapolite, plagioclase, four types of vesuvianite (a, b, c, and d), and calcite (Table 1). It has porphyroblastic texture and medium to coarse grain size. The carbonate matrix constitutes less than $20 \%$ of the calcic skarn and is composed of calcite crystals ( $\mathrm{Cal}_{98.77-99.98 \%}$ $\mathrm{Mgs}_{0.00-0.58 \%}$; Appendix A.1) of 1-2 mm in diameter with granoblastic texture. Calcite replaces some calc-silicate minerals to variable degrees and fills fractures and cavities. Titanite, amphibole, apatite, zircon, epidote, and quartz are accessory minerals.

5.2.1.1. Paragenesis 1. This paragenesis is mainly composed of type 1 garnet, type I clinopyroxene, wollastonite, and calcite. It also contains minor amounts of scapolite and plagioclase. Porphyroblasts of these minerals are immersed in a scarce carbonate matrix. In some sectors, the carbonate matrix is so scarce that only a mass almost totally constituted by calc-silicate minerals is observed. Paragenesis 1 constitutes the central sector of LM-9 (Fig. 3) and LM-10 (not shown) skarn outcrops and is surrounded by paragenesis 2 (see next section).

Type 1 garnet consists of subhedral to euhedral crystals with diameters up to $500 \mu \mathrm{m}$, anomalous anisotropy, and hourglass-shaped twins (Fig. 4a); its composition is andraditic grossular ( $\mathrm{Grs}_{72.62-90.61 \%}$ $\mathrm{Adr}_{4.50-26.49 \%}$; Fig. 4e-f and Appendix A.2). Type I clinopyroxene consists of dark green (Fig. 5a), anhedral, and subrounded crystals with lengths up to $4 \mathrm{~mm}$; its composition is diopsidic hedenbergite ( $\mathrm{Di}_{42.81-48.45 \%} \mathrm{Hd}_{50.98-56.66 \%}$; Fig. 5c-d and Appendix A.3).

Wollastonite exhibits prismatic or fibrous habit (parallel or
Fig. 3. Scheme of the main calcic skarn outcrops (LM-9 in Fig. 1c). Paragenesis 1 (e.g., LM-9b) constitutes the central sector of the outcrop and is surrounded by paragenesis 2 (e.g., LM-9a and LM-9d). Solid and dashed black lines show the trace of the foliation and fracture planes, respectively. Abbreviations: $\mathrm{Cal}=$ calcite, $\mathrm{Cpx}=$ clinopyroxene, $\mathrm{Grt}=$ garnet, $\mathrm{Wo}=$ wollastonite.
LM-9d

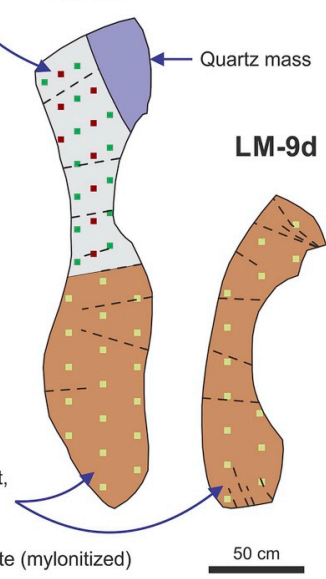

radiated) with lengths up to $1 \mathrm{~cm}$ (Fig. 6); some crystals are flexured. EMP analyses of wollastonite from the Loma Marcelo skarn are very close to the extreme pure end-member of the composition (Wo ${ }_{96.62-99.77 \%} \mathrm{En}_{0.00-0.53 \%} \mathrm{Fs}_{0.21-2.85 \%}$; Appendix A.4).

Scapolite and plagioclase are usually found together. Scapolite crystals are anhedral and have irregular edges and a maximum length of $3 \mathrm{~mm}$. The identification of second order interference colours allows scapolite to be characterized as meionite (marialite exhibits first order interference colours). Plagioclase crystals are also anhedral and have irregular edges and lengths up to $5 \mathrm{~mm}$. Maximum extinction angles of $45^{\circ}\left( \pm 2^{\circ}\right)$ allow plagioclase to be characterized as bytownite $\left(\mathrm{An}_{76-83}\right)$. Meionite and bytownite from the Loma Marcelo skarn have $\mathrm{Al} / \mathrm{Si}$ ratios of approximately 0.7 and 0.8 , respectively. These results were obtained by X-ray dispersive energy on the basis of $12(\mathrm{Si}+\mathrm{Al})$ cations for scapolite and 8 oxygen atoms for plagioclase.

5.2.1.2. Paragenesis 2 . This paragenesis is mainly composed of type 2 garnet, type II clinopyroxene, vesuvianite (types a, b, c, and d), and calcite. Porphyroblasts of these minerals are immersed in a scarce carbonate matrix, forming masses around the minerals that constitute paragenesis 1 (e.g., LM-9 and LM-10; Fig. 1c) (Fig. 3). LM-13 skarn outcrop consists mainly of paragenesis 2 , with minor and subordinate paragenesis 1 .

Type 2 garnet forms irregular centimetric masses with anomalous anisotropy and strong fracturing (Fig. 4b) and is grossularitic in composition ( $\mathrm{Grs}_{85.64-98.84 \%} \mathrm{Adr}_{0.00-9.04 \%}$; Fig. 4e-f and Appendix A.2).

Table 1

Location and mineralogical composition of skarn outcrops identified at Loma Marcelo (Fig. 1c).

\begin{tabular}{|c|c|c|c|c|}
\hline \multirow[t]{2}{*}{ Skarn outcrops } & \multicolumn{2}{|c|}{ Coordinates } & \multirow[t]{2}{*}{ Skarn type } & \multirow[t]{2}{*}{ Main mineralogy } \\
\hline & Latitude & Longitude & & \\
\hline LM-4 & $37^{\circ} 55^{\prime} 49.20^{\prime \prime} \mathrm{S}$ & $62^{\circ} 10^{\prime} 28.60^{\prime \prime} \mathrm{W}$ & Calcic & Garnet (type 3), clinopyroxene (type II), meionite, bytownite, calcite, quartz, titanite \\
\hline LM-6 & $37^{\circ} 55^{\prime} 54.60^{\prime \prime} \mathrm{S}$ & $62^{\circ} 10^{\prime} 29.97^{\prime \prime} \mathrm{W}$ & Magnesian & Calcite, dolomite, forsterite (relictic), spinel, chondrodite, dozyite, quartz \\
\hline LM-9a & $37^{\circ} 55^{\prime} 53.52^{\prime \prime} \mathrm{S}$ & $62^{\circ} 10^{\prime} 27.47^{\prime \prime} \mathrm{W}$ & Calcic & $\begin{array}{c}\text { Garnet (types } 1,2 \& 3 \text { ), clinopyroxene (types I \& II), wollastonite, vesuvianite (type a), meionite, bytownite, } \\
\text { calcite, quartz, titanite }\end{array}$ \\
\hline LM-9b & & & & Garnet (types 1, 2 \& 3), clinopyroxene (types I \& II), wollastonite, meionite, bytownite, calcite, quartz, titanite \\
\hline LM-9c & & & & Garnet (types $1,2 \& 3$ ), clinopyroxene (types I \& II), wollastonite, vesuvianite (type a), meionite, bytownite, \\
\hline LM-9d & & & & calcite, quartz, titanite \\
\hline LM-10 & $37^{\circ} 55^{\prime} 54.42^{\prime \prime} \mathrm{S}$ & $62^{\circ} 10^{\prime} 27.13^{\prime \prime} \mathrm{W}$ & Calcic & $\begin{array}{c}\text { Garnet (types 1, } 2 \& \text { 3), clinopyroxene (types I \& II), wollastonite, vesuvianite (type b), meionite, bytownite, } \\
\text { calcite, quartz, titanite }\end{array}$ \\
\hline LM-12 & $37^{\circ} 55^{\prime} 53.10^{\prime \prime} \mathrm{S}$ & $62^{\circ} 10^{\prime} 28.45^{\prime \prime} \mathrm{W}$ & Calcic & $\begin{array}{c}\text { Garnet (types 1, } 2 \& 3 \text { ), clinopyroxene (types I \& II), wollastonite, vesuvianite (type a), meionite, bytownite, } \\
\text { calcite, quartz, titanite }\end{array}$ \\
\hline LM-13 & $37^{\circ} 55^{\prime} 52.00^{\prime \prime} \mathrm{S}$ & $62^{\circ} 10^{\prime} 28.00^{\prime \prime} \mathrm{W}$ & Calcic & Garnet (types 1 \& 2), vesuvianite (types c \& d), clinopyroxene (relictic), calcite, quartz \\
\hline
\end{tabular}



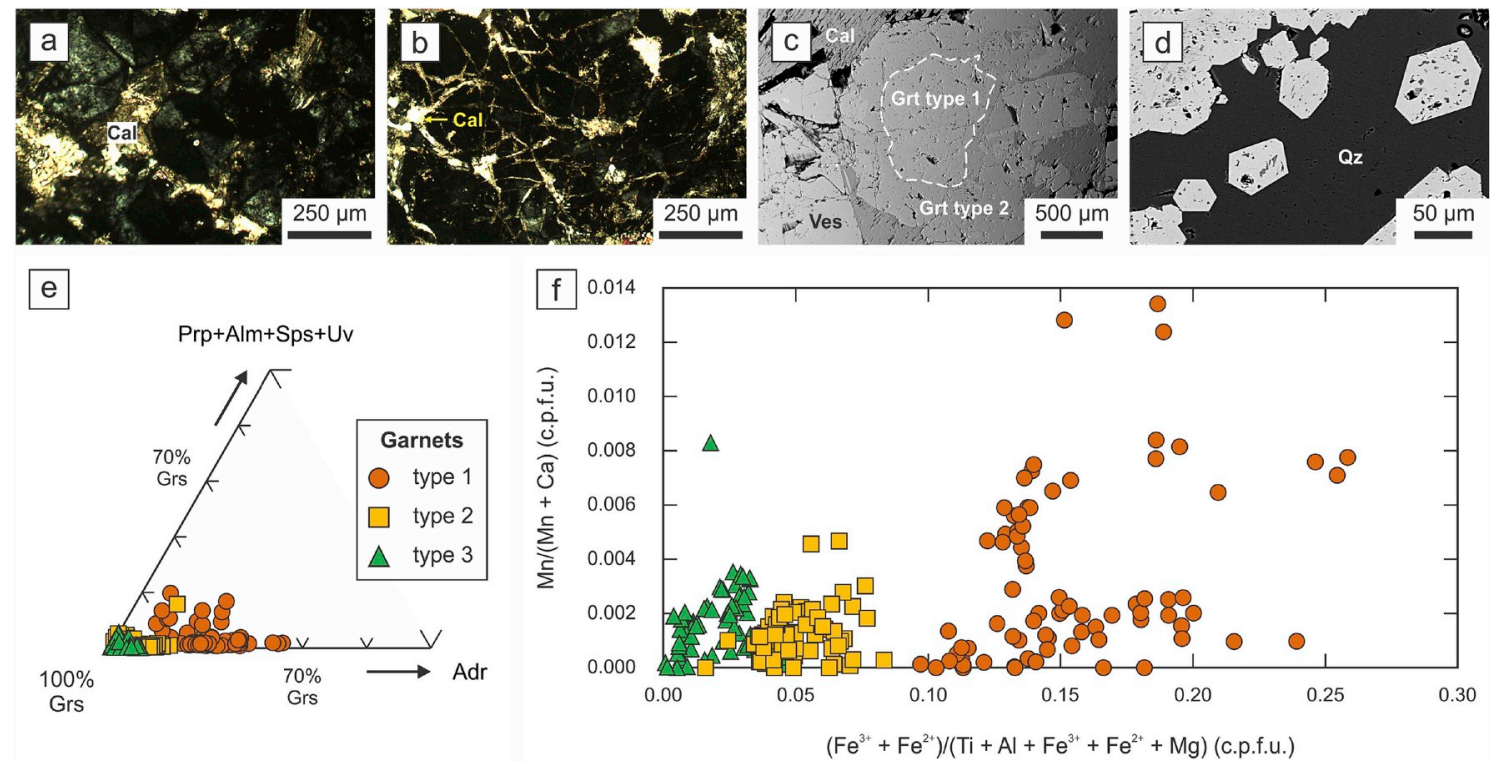

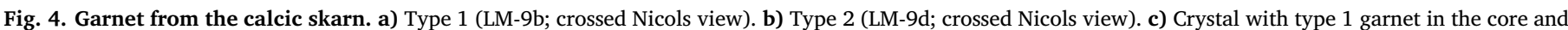

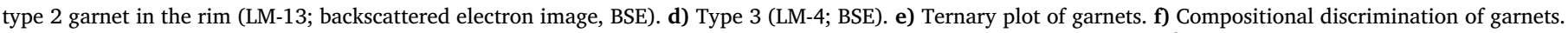

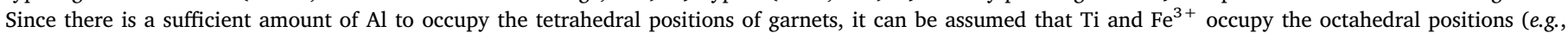

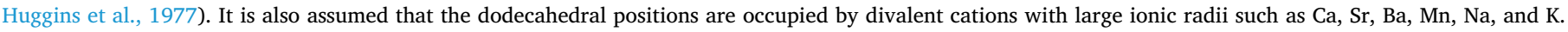

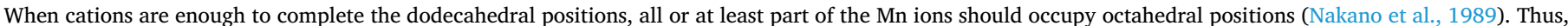

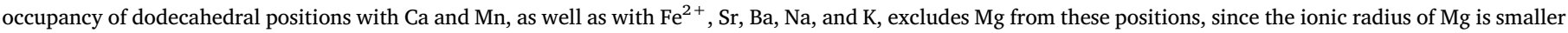

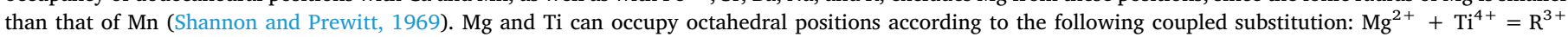

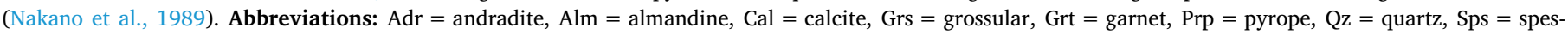
sartine, $\mathrm{Uv}=$ uvarovite, Ves = vesuvianite, c.p.f.u. = cations per formula unit.

Some subhedral to euhedral crystals with oscillatory zoning exhibit andraditic grossular cores (composition of type 1 garnet) and essentially grossularitic rims (composition of type 2 garnet) (Fig. 4c), revealing that the formation of type 1 occurred before that of type 2 . Type II clinopyroxene consists of light green (Fig. 5b) and subhedral to euhedral crystals with lengths up to $7 \mathrm{~mm}$; its composition is hedenbergitic diopside $\left(\mathrm{Di}_{63.42-87.27 \%} \mathrm{Hd}_{12.39-35.79 \%}\right.$; Fig. $5 \mathrm{c}-\mathrm{d}$ and Appendix A.3). Additionally, type II clinopyroxene crystals are less altered and fractured than crystals of type I clinopyroxene.

Vesuvianite samples from LM-9, LM-10, and LM-13 skarn outcrops (Fig. 1c) were chemically analysed using EMP. Four types of vesuvianite were identified: a, b, c, and d. In hand sample, type a vesuvianite is
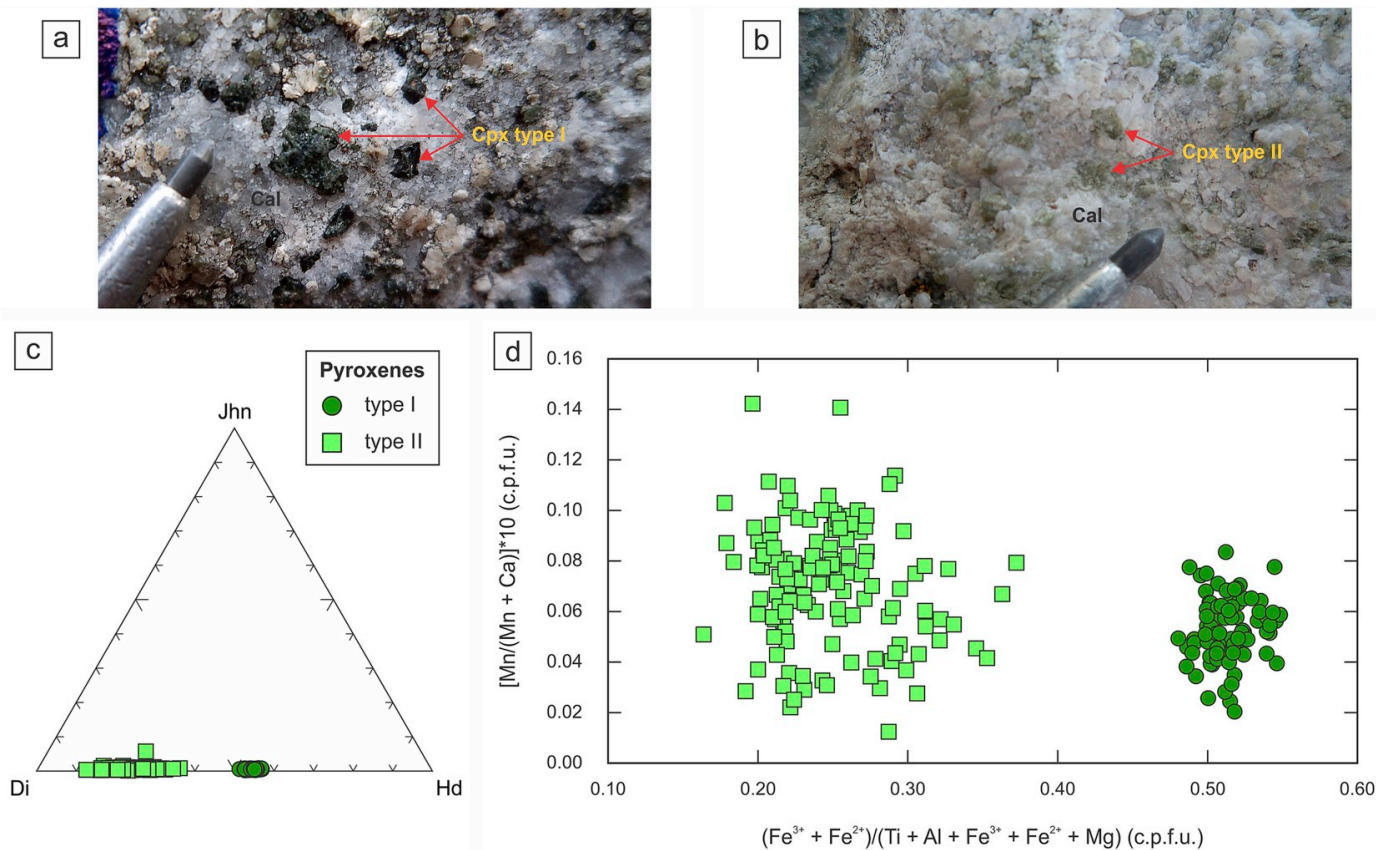

Fig. 5. Clinopyroxene from the calcic skarn. a) Type I, dark green colour (detail of LM-9). b) Type II, light green colour (detail of LM-9). c) Ternary plot of clinopyroxenes. d) Compositional discrimination of clinopyroxenes. Abbreviations: Cal = calcite, Cpx $=$ clinopyroxene, $\mathrm{Di}=$ diopside, $\mathrm{Hd}=$ hedenbergite, $\mathrm{Jhn}=$ johannsenite, c.p.f.u. $=$ cations per formula unit. (For interpretation of the references to colour in this figure legend, the reader is referred to the Web version of this article.) 

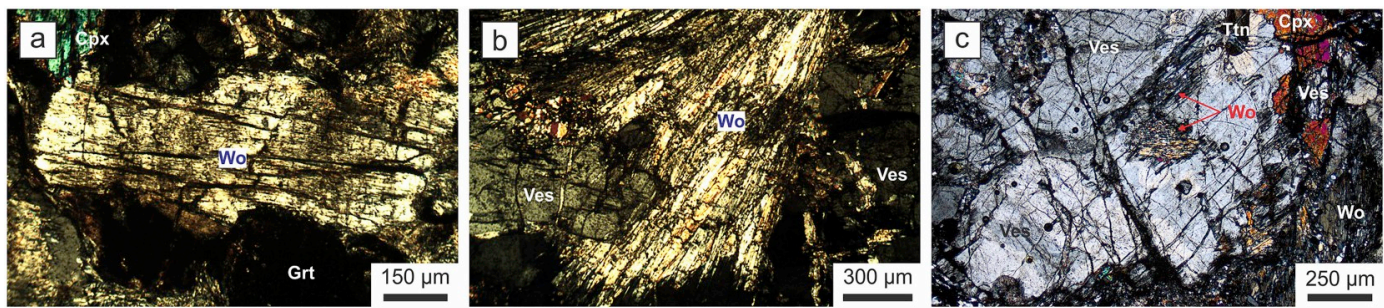

Fig. 6. Wollastonite from the calcic skarn. a) Aggregate with parallel fibrous habit (LM-9; crossed Nicols view). b) Aggregate with radiated fibrous habit (LM-10; crossed Nicols view); note the formation of vesuvianite from wollastonite. c) Wollastonite (and clinopyroxene) replaced by vesuvianite (LM-9; crossed Nicols view). Abbreviations: $\mathrm{Cpx}=$ clinopyroxene, $\mathrm{Grt}=$ garnet, $\mathrm{Ttn}=$ titanite, Ves $=$ vesuvianite, Wo $=$ wollastonite.

reddish brown (Fig. 7a), types b and c are brownish green (Fig. 7c, e), and type $d$ is blue (not shown and not analysed). The brown and green varieties exhibit prismatic and radiated prismatic habits (Fig. 7b, f); they also form centimetric masses (Fig. 7d). The blue variety is scarce and interstitial. The interference figure may occur as uniaxic or biaxic. However, the optical sign is always negative, which indicates that vesuvianites from the Loma Marcelo skarn are boron-free normal vesuvianites (Groat et al., 1992).

The colours of vesuvianites are a consequence of their different $\mathrm{Fe}$ and Ti contents (Manning, 1975). The green vesuvianites (types b and c) have high $\mathrm{FeO}_{\mathrm{T}}(4.05-5.30 \%)$ and low $\mathrm{TiO}_{2}(\leq 1.24 \%)$ contents, whereas the brown vesuvianite (type a) has somewhat lower contents of $\mathrm{FeO}_{\mathrm{T}}(3.50-5.34 \%)$ and higher contents of $\mathrm{TiO}_{2}(\leq 3.82 \%)$ (Fig. $7 \mathrm{~g}$; Appendix A.5). The blue variety (type d) is known as cyprine and its colour is caused by the presence of $\mathrm{Cu}$ impurities (Fitzgerald et al., 1986). The F content of the analysed vesuvianites reaches up to $2.70 \%$ $\left(\mathrm{X}_{\mathrm{F}}=0.33\right.$ in average). Fig. $7 \mathrm{~h}$ shows the composition of vesuvianites from the Loma Marcelo skarn plotted in an AFM diagram. The absence of boron can be easily recognized through the $\mathrm{Al}$ vs. $\mathrm{Mg}$ diagram of Groat et al. (1992) (Fig. 7i).
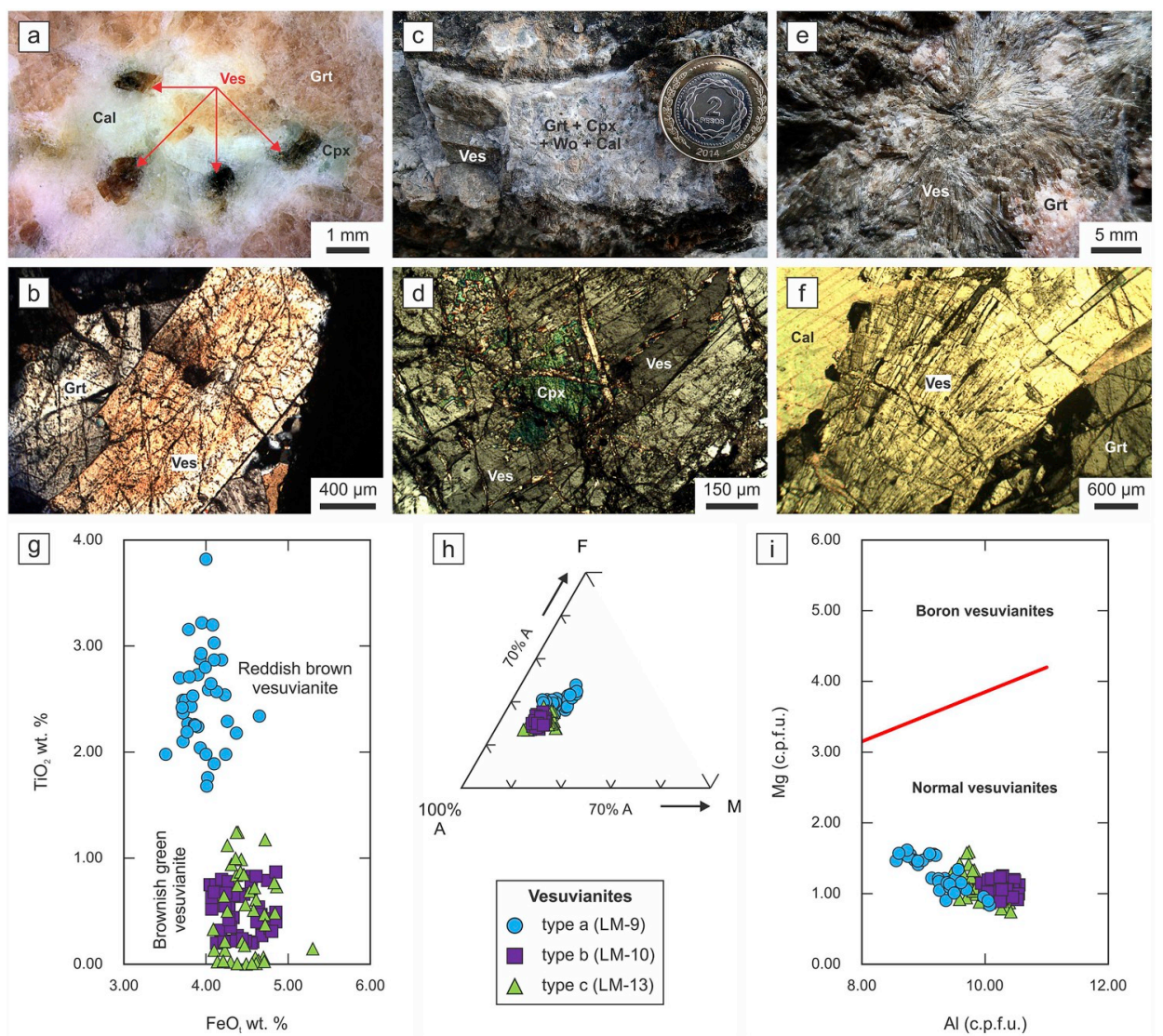

The structural formula of vesuvianite can be represented as $\mathrm{X}_{19} \mathrm{Y}_{13}$ $\mathrm{T}_{0-5}{ }^{\mathrm{O}} \mathrm{Z}_{10}{ }^{\mathrm{D}} \mathrm{Z}_{8} \mathrm{O}_{68} \mathrm{~W}_{10-11}$, where the "O" and "D" superscripts refer to the orthosilicate $\left(\mathrm{SiO}_{4}\right)$ and disilicate $\left(\mathrm{Si}_{2} \mathrm{O}_{7}\right)$ groups, respectively. $\mathrm{X}$ sites are mainly occupied by $\mathrm{Ca}^{2+}$ and $\mathrm{Na}^{+}, \mathrm{Y}$ sites by $\mathrm{Al}^{3+}, \mathrm{Mg}^{2+}$, $\mathrm{Fe}^{2+/ 3+}, \mathrm{Mn}^{2+/ 3+}$, and $\mathrm{Ti}^{4+}, \mathrm{Z}$ sites by $\mathrm{Si}$ and $\mathrm{W}$ sites by $\mathrm{OH}, \mathrm{F}$, and $\mathrm{O}$ (Groat et al., 1992; Gnos and Armbruster, 2006). Vesuvianites with T site vacancies $\left(\mathrm{T}_{0}\right)$ have $\mathrm{W}=10\left(\mathrm{~W}_{10}\right)$, whereas those with triangularcoordinated boron occupying $\mathrm{T}$ sites $\left(\mathrm{T}_{5}\right)$ have $\mathrm{W}=11\left(\mathrm{~W}_{11}\right)$. Vesuvianites from the Loma Marcelo skarn can be expressed as

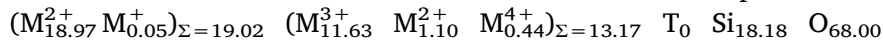
$\left(\mathrm{OH}_{6.81} \mathrm{~F}_{2.87} \mathrm{Cl}_{0.31}\right)_{\Sigma=10.00}$. X sites are completely occupied. The excess of cations in the $\mathrm{Y}$ sites could be considered within the error range, $13.17 \pm 0.25$ cations per formula unit (c.p.f.u.), suggesting the absence of boron and other cations in the T sites (Gnos and Armbruster, 2006). EMP analyses of vesuvianite from the Loma Marcelo skarn are provided in Appendix A.5.

5.2.1.3. Other minerals. In addition to the minerals described above, a third type of garnet, titanite, amphibole, apatite, zircon, epidote, quartz, and galena were identified. 
Type 3 garnet fills small cavities between the minerals of paragenesis 1 and 2 (e.g., LM-9, LM-10) or forms irregular masses around the minerals that constitute paragenesis 2 (e.g., LM-9). LM-4 skarn outcrop is mainly composed of type 3 garnet. In all cases, type 3 garnet consists of euhedral dodecahedral crystals up to $100 \mu \mathrm{m}$ in diameter that are completely isotropic and scarcely fractured (Fig. 4d); its composition is almost pure grossular (Grs $95.17-99.82 \% \mathrm{Adr}_{0.00-4.67 \%}$; Fig. $4 \mathrm{e}-\mathrm{f}$ and Appendix A.2).

Titanite crystals are frequent and spread throughout the carbonate matrix. They are anhedral to subhedral and commonly sub-rounded, with a maximum length of $2 \mathrm{~mm}$ (Fig. 8a). Ballivián Justiniano et al. (2017) determined the existence of compositional zoning with low-F cores $(1.73 \%)$ and high-F rims $(2.12-2.47 \%)$. Amphibole (tremolite-actinolite) with a radiating fibrous habit was also identified replacing garnet, clinopyroxene, and vesuvianite crystals of paragenesis 1 and 2 in variable degree (Fig. 8b).

Apatite is scarce and consists of euhedral crystals with hexagonal basal sections up to $250 \mu \mathrm{m}$ in diameter. Zircon crystals have prismatic habit and are up to $250 \mu \mathrm{m}$ long. Epidote (zoisite/clinozoisite) replaces calc-silicate minerals of paragenesis 1 and 2 in variable degree (Fig. 8c); it also appears as scattered grains throughout the carbonate matrix. Finally, quartz crystals up to $100 \mu \mathrm{m}$ in diameter constitute small interstitial mosaics with granoblastic texture. Veins and masses of quartz cut the calcic skarn. Small quantities of galena were found in a quartz vein that cuts LM-9.

\subsubsection{Magnesian skarn (chondrodite-bearing assemblage)}

The surface of the only body of magnesian skarn identified is notably rugous due to the differential resistance of its minerals to the effects of dissolution by weathering (Fig. 9a). The magnesian skarn is yellowish white to whitish orange on fresh surfaces (Fig. 9b) and dark grey where serpentinization is intense (Fig. 9c). It consists of a carbonate matrix composed of dolomite and calcite, in which porphyroblasts of chondrodite and spinel are immersed (Table 1). Forsterite was identified inside chondrodite crystals. Fluorite and quartz are accessory minerals. Dozyite, serpentine, and pyrophyllite appear as alteration minerals of chondrodite and spinel.

The magnesian skarn has a higher content of carbonate minerals $(60-80 \%)$ than the calcic skarn. Dolomite ( $\mathrm{Cal}_{51.13-55.29 \%}$ $\left.\mathrm{Mgs}_{44.18-48.35 \%}\right)$ and calcite $\left(\mathrm{Cal}_{95.21-98.31 \%} \mathrm{Mgs}_{1.38-4.60 \%}\right)$ constitute both the matrix and the carbonate cores and patches in some chondrodite crystals (Appendix A.1). Carbonate minerals develop crystals up to 1-2 mm long with granoblastic texture (Fig. 9d). Exsolution textures between both carbonates were also observed. The edges of calcite and dolomite crystals are lobed and jagged due to dynamic recrystallization processes (Fig. 9d).

Chondrodite, a humite-group mineral, is pale yellow to orangeyellow in hand specimen and exhibits orange fluorescence under shortwave ultraviolet light. The crystals are anhedral and slightly elongated with irregular edges and maximum lengths of $1 \mathrm{~cm}$ (Fig. 9e and f). They have simple or polysynthetic twins (Fig. 9g). Chondrodite seems to have grown around dolomite (Fig. 9e and f) and forsterite (Fig. 9h), forming coronitic textures. Some of the forsterite crystals contain calcite inclusions. Small inclusions of pyrite and Co-bearing pyrite were also identified in some chondrodite crystals.

The general formula of the humite-group minerals can be represented as $\mathrm{M}_{2 \mathrm{n}-1} \mathrm{Si}_{\mathrm{n}} \mathrm{O}_{2 \mathrm{n}} 2 \mathrm{M}(\mathrm{OH}, \mathrm{F}) \mathrm{O}$, where $\mathrm{M}$ is the sum of $\mathrm{Mg}$, $\mathrm{Fe}^{2+}, \mathrm{Mn}, \mathrm{Ca}, \mathrm{Zn}$, etc., and $\mathrm{n}=1$ for norbergite, $\mathrm{n}=2$ for chondrodite, $\mathrm{n}=3$ for humite, and $\mathrm{n}=4$ for clinohumite (Deer et al., 1992). Following the general formula, the $\mathrm{M} / \mathrm{Si}$ ratio for each mineral in the humite-group is different (Jones et al., 1969): 3.00 for norbergite, 2.50 for chondrodite, 2.30 for humite, and 2.25 for clinohumite. Chondrodite from the Loma Marcelo skarn has an average M/Si ratio of 2.61 ( \pm 0.06 ) (Appendix A.6), which is close to the ideal value for chondrodite.

$\mathrm{Mg}$ is the most important and abundant octahedrally coordinated cation in the humite-group minerals and $\mathrm{Fe}^{2+}$ is its main substitute. Chondrodite from the Loma Marcelo skarn has mean contents of $\mathrm{MgO}$ and $\mathrm{FeO}_{\mathrm{T}}$ of $57.95 \%$ and $0.63 \%$, respectively $\left(\mathrm{X}_{\mathrm{Mg}}=0.99\right.$ in average), and reaches $0.25 \% \mathrm{TiO}_{2}, 0.17 \% \mathrm{MnO}, 0.10 \% \mathrm{CaO}$, and $0.18 \% \mathrm{ZnO}$ (Appendix A.6). The mean F content is $8.69 \%\left(\mathrm{X}_{\mathrm{F}}=0.75\right.$ in average).

Dolomite and forsterite were identified within chondrodite crystals, forming coronitic textures (Fig. 9e, f, h). This fact suggests the formation of chondrodite by replacement of dolomite and forsterite. The replacement of forsterite to form chondrodite (chondroditization) would have occurred along grain boundaries and fractures. Forsterite from the Loma Marcelo skarn is highly magnesium-rich (Fo98.10-99.00\% $\mathrm{Fa}_{1.00-1.90 \%}$; Appendix A.7). Inclusions of calcite were identified in some of the analysed forsterite crystals.

Spinel crystals are frequent. They show euhedral forms with octahedral, rectangular, and trapezoidal sections (Fig. 9i). These crystals are bluish grey in hand specimen with diameters up to $3 \mathrm{~mm}$. Spinel from the Loma Marcelo skarn mainly consists of spinel sensu stricto (Spl ${ }_{95.86-97.12 \%}$; Appendix A.8). The substitution of $\mathrm{Mg}$ by $\mathrm{Fe}^{2+}, \mathrm{Mn}$, and $\mathrm{Zn}$ occurs scarcely, as the molecular proportions of hercynite, galaxite, and gahnite are all lower than $5 \%\left(\mathrm{Hc}_{2.50-3.83 \%} \mathrm{Gl}_{0.05-0.33 \%}\right.$ $\left.\mathrm{Ghn}_{0.00-0.27 \%}\right)$.

In addition to the minerals described above, dozyite, serpentine, pyrophyllite, fluorite, and quartz were identified. The dozyite is a 1:1 interstratification of serpentine and chlorite, whose general formula is $\left(\mathrm{Mg}_{7} \mathrm{Al}_{2}\right)\left(\mathrm{Si}_{4} \mathrm{Al}_{2}\right) \mathrm{O}_{15}(\mathrm{OH})_{12}$. In the Loma Marcelo skarn, dozyite was identified by XRD. Dozyite crystals appear dispersed in the carbonate matrix (Fig. 9i) and replacing chondrodite and spinel crystals (Fig. 9j). They have a laminar habit (some sheets are flexured), perfect cleavage and undulating extinction. EMP analyses of dozyite from the Loma Marcelo skarn are provided in Appendix A.9.

Serpentinization is the dominant alteration in the magnesian skarn, being selective and of variable intensity. Antigorite appears as microcrystalline aggregates replacing chondrodite, spinel, and/or dozyite (Fig. 9i-k) and is often accompanied by flakes of pyrophyllite. Chrysotile is arranged perpendicular to the grain edges of altered chondrodite and spinel crystals (Fig. 9k), sometimes surrounding them, and
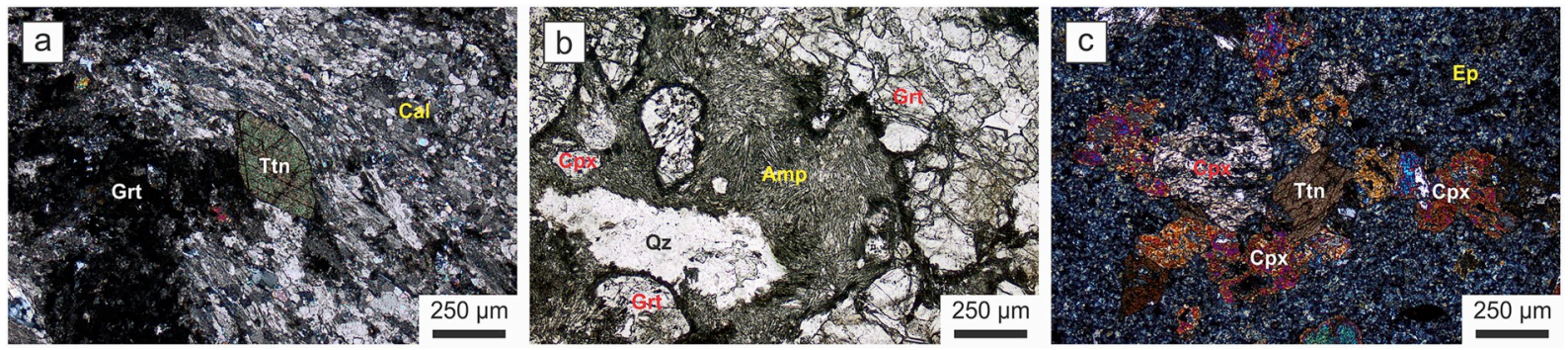

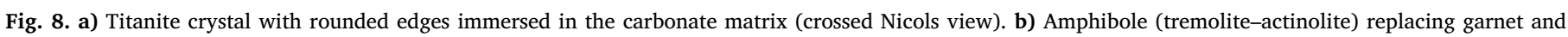

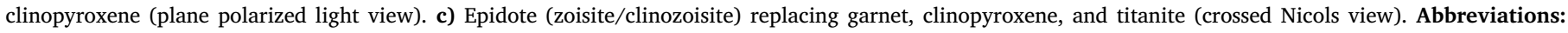
$\mathrm{Amp}=$ amphibole, $\mathrm{Cal}=$ calcite, $\mathrm{Cpx}=$ clinopyroxene, $\mathrm{Ep}=$ epidote, Grt $=$ garnet, $\mathrm{Qz}=$ quartz, Ttn $=$ titanite. 

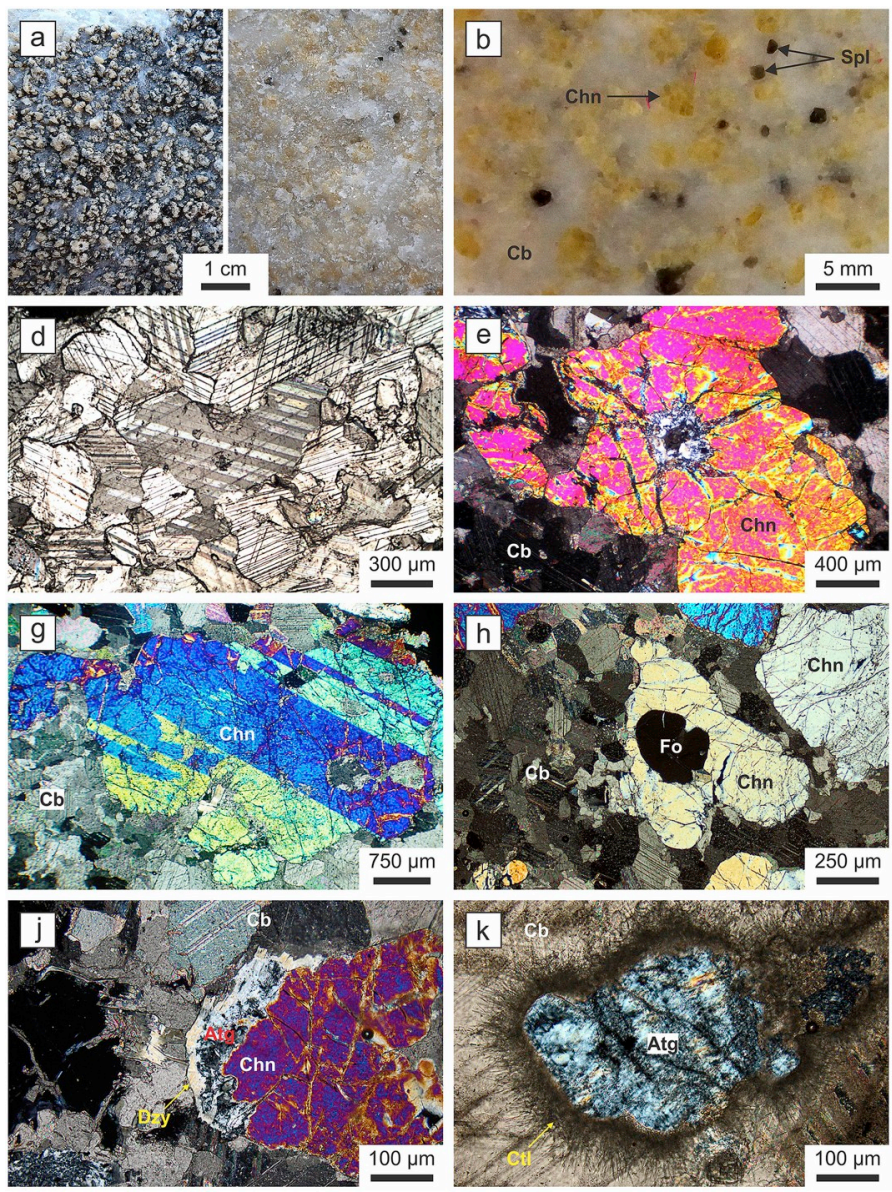
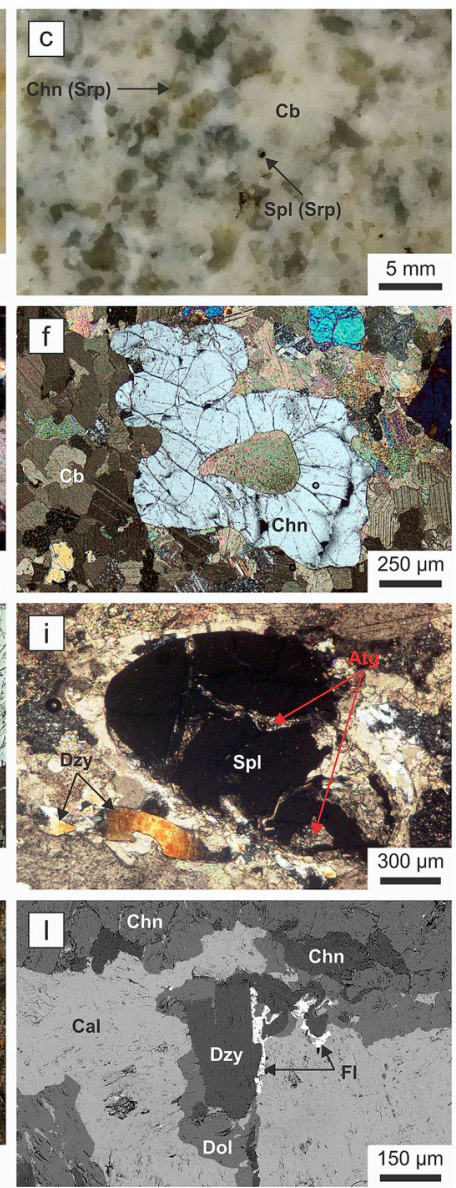

Fig. 9. Magnesian skarn. a) Weathered (left) and fresh (right) magnesian skarn (LM-6 in Fig. 1c). b) Polished hand sample of the unaltered magnesian skarn. c) Polished hand sample of the serpentinized magnesian skarn. d) Detail of the carbonate matrix (calcite + dolomite) with granoblastic texture; the lobed and jagged edges are due to dynamic recrystallization processes. e, f) Chondrodite developed around dolomite, forming a coronitic texture (crossed Nicols view). g) Chondrodite crystal with polysynthetic twins immersed in the carbonate matrix (crossed Nicols view). h) Chondrodite developed around forsterite (extinguished), forming a coronitic texture (crossed Nicols view). i) Spinel and dozyite immersed in the carbonate matrix (crossed Nicols view); the spinel crystal is incipiently serpentinized along fractures. j) Dozyite altering a chondrodite crystal and both being altered by antigorite (crossed Nicols view). k) Antigorite pseudomorph after chondrodite surrounded by chrysotile (crossed Nicols view). 1) Dozyite associated with chondrodite and fluorite (backscattered electron image). Abbreviations: $\mathrm{Atg}=$ antigorite, $\mathrm{Cal}$ $=$ calcite, $\mathrm{Cb}=$ carbonate $(\mathrm{cal}-$ cite + dolomite), $\mathrm{Chn}=$ chondrodite, Ctl $=$ chrysotile, Dol $=$ dolomite, Dzy = dozyite, $\mathrm{Fl}=$ fluorite, Spl = spinel sensu stricto, Srp $=$ serpentine. appears close to carbonates and antigorite inside veinlets up to $2 \mathrm{~mm}$ wide. Fluorite was identified along fractures and grain edges of chondrodite, spinel, and dozyite crystals (Fig. 9 1), whereas quartz is dispersed in the carbonate matrix.

\section{Metamorphic evolution of the Loma Marcelo skarn}

The Loma Marcelo skarn is the result of at least three metamorphic events due to the interaction of chemically reactive rocks with hydrothermal fluids. In this section, a chronologic sequence of the metamorphic events is described using the above-mentioned mineralogical and textural features.

\subsection{First metamorphic event (M1)}

The juxtaposition of materials with great compositional contrast was characterized by the development of high chemical gradients, favouring the formation of garnet (type 1), clinopyroxene (type I), wollastonite, meionite, and bytownite in the calcic skarn (paragenesis 1) and forsterite and spinel in the magnesian skarn (Fig. 10). During the retrograde stage, titanite would have been formed in the calcic skarn. No retrograde minerals attributable to this event were identified in the magnesian skarn.

\subsubsection{Calcic skarn (paragenesis 1)}

Type 1 garnet $\left(\mathrm{Grs}_{72.62-90.61 \%} \mathrm{Adr}_{4.50-26.49 \%}\right.$ ) and type I clinopyroxene $\left(\mathrm{Di}_{42.81-48.45 \%} \mathrm{Hd}_{50.98-56.66 \%}\right)$ are the dominant minerals in the calcic skarn, followed by wollastonite (Wo-96.62-99.77\% $\mathrm{En}_{0.00-0.53 \%} \mathrm{Fs}_{0.21-2.85 \%}$ ), and represent the first products of metasomatism during the M1 event (Fig. 10). Calcite, meionite, and bytownite are also present. The paragenesis garnet-clinopyroxene-wollastonite-plagioclase-calcite is typical of impure calcitic protoliths affected by infiltration of an aqueous fluid phase during high-temperature/low-pressure metamorphism (e.g., Bucher and Grapes, 2011).

The presence of wollastonite is indicative of low $\mathrm{X}_{\mathrm{CO} 2}$ and high fluid/rock ratio (Hoisch, 1985; Ferry, 1986). The metasomatic introduction of silica by aqueous fluids promote the formation of wollastonite by the reaction Calcite $+\mathrm{SiO}_{2} \leftrightarrow$ Wollastonite $+\mathrm{CO}_{2}$ (Fig. 11a). In siliceous limestones and calc-silicate marbles affected by contact metamorphism, wollastonite can be formed even in closed system conditions if an aqueous pore fluid is available (Bucher and Grapes, 2011). In presence of an aqueous fluid phase and at $100 \mathrm{MPa}$, detectable amounts of wollastonite form at $500{ }^{\circ} \mathrm{C}$ and its stability field extends above $700{ }^{\circ} \mathrm{C}$ (Fig. 11a).

The assemblage garnet-clinopyroxene-wollastonite has a stability field that extends from about $300{ }^{\circ} \mathrm{C}$ to above $700{ }^{\circ} \mathrm{C}$ at $100 \mathrm{MPa}$ (Fig. 11a). Under the physical conditions that a carbonate xenolith of calcic composition would experience during contact metamorphism (e.g., $650{ }^{\circ} \mathrm{C}$ and $100 \mathrm{MPa}$ ), the maximum value of $\mathrm{X}_{\mathrm{CO} 2}$ for the assemblage garnet-clinopyroxene-wollastonite is 0.38 (Fig. 11a).

The scapolite-plagioclase assemblage is frequent in skarns. This assemblage is stable over a wide range of pressures and is usually indicative of temperature conditions typical of the hornblende- and pyroxene-hornfels facies (e.g., Pan, 1998). In the Loma Marcelo skarn, the scapolite and plagioclase were petrographically identified as meionite and bytownite, respectively. $\mathrm{Al} / \mathrm{Si}$ ratios of about 0.7 are typical of scapolites formed above $600^{\circ} \mathrm{C}$ (Oterdoom and Wenk, 1983). Textural equilibrium between plagioclase and scapolite suggests that the scapolite-forming reaction was 3 Anorthite + Calcite $\leftrightarrow$ Scapolite (Kuhn et al., 2005). 


\begin{tabular}{|c|c|c|c|c|c|c|}
\hline & \multicolumn{2}{|c|}{ 1st metamorphism (M1) } & \multicolumn{2}{|c|}{ 2nd metamorphism (M2) } & \multicolumn{2}{|c|}{ 3th metamorphism (M3) } \\
\hline & Prograde & Retrograde & Prograde & Retrograde & Prograde & Retrograde \\
\hline \multicolumn{7}{|c|}{ Calcic skarn } \\
\hline Garnet & $=$ & & $=$ & & & - \\
\hline Clinopyroxene & - & & - & & & \\
\hline Wollastonite & 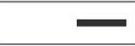 & & & & & \\
\hline Meionite & $=--=$ & & & & & \\
\hline Bytownite & $=-2=$ & & & & & \\
\hline \multicolumn{7}{|l|}{ Vesuvianite } \\
\hline \multicolumn{7}{|l|}{ Titanite } \\
\hline Amphibole & & & & & 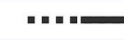 & -".. \\
\hline Epidote & & & & & 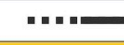 & E... \\
\hline \multicolumn{7}{|c|}{ Magnesian skarn } \\
\hline Forsterite & 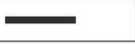 & & & & & \\
\hline Spinel & $\longrightarrow$ & & & & & \\
\hline \multicolumn{7}{|l|}{ Chondrodite } \\
\hline \multicolumn{7}{|l|}{ Fluorite } \\
\hline \multicolumn{7}{|l|}{ Dozyite } \\
\hline Serpentine & & & & & 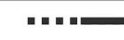 & -". \\
\hline
\end{tabular}

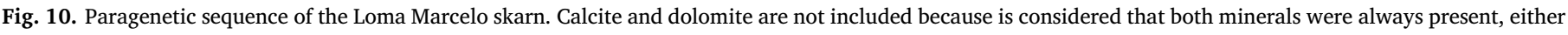
as primary minerals in carbonate protoliths (calcite and dolomite) or as products of some metamorphic reactions (calcite).

\subsubsection{Magnesian skarn}

Forsterite and spinel were formed in the magnesian skarn during the M1 event (Fig. 10). Assemblages with forsterite are characteristic of dolostones close to the igneous contacts or in xenoliths incorporated by intrusive bodies. Several reactions have been proposed to explain the formation of forsterite in dolomitic protoliths during contact metamorphism. Some of these reactions require silicates such as tremolite and diopside, in addition to dolomite, to produce forsterite and calcite (e.g., Bucher and Grapes, 2011) (Fig. 11b):

11 Dolomite + Tremolite $\leftrightarrow 13$ Calcite +8 Forsterite $+9 \mathrm{CO}_{2}+\mathrm{H}_{2} \mathrm{O}$

\section{Dolomite + Diopside $\leftrightarrow 4$ Calcite +2 Forsterite $+2 \mathrm{CO}_{2}$}

The coexistence of dolomite-tremolite-forsterite-calcite and dolomite-diopside-forsterite-calcite is evidence of these reactions (e.g., Ferry et al., 1998, 2002). However, none of them was identified in the
Loma Marcelo skarn.

In the magnesian skarn, forsterite was formed at about $650{ }^{\circ} \mathrm{C}$. This temperature was calculated from the composition of calcite inclusions in forsterite, following Anovitz and Essene (1987), assuming that the calcite inclusions were in equilibrium with dolomite when forsterite formed. The calculated temperature is higher than the temperature at which isobaric univariant assemblages dolomite-tremolite-forsterite-calcite and dolomite-diopside-forsterite-calcite can coexist in equilibrium with a $\mathrm{H}_{2} \mathrm{O}-\mathrm{CO}_{2}$ fluid phase (Ferry et al., 2011). This implies that forsterite was formed from reactions that do not involve tremolite or diopside as reactants and/or under conditions far from equilibrium. Forsterite can also be the result of the reaction 2 Dolomite $+\mathrm{SiO}_{2} \leftrightarrow$ Forsterite +2 Calcite $+2 \mathrm{CO}_{2}$, where the silica source can be quartz from the protolith (e.g., Müller et al., 2004) or dissolved silica introduced by aqueous fluids into the protolith (e.g., BucherNurminen, 1982; Holness, 1997; Bucher, 1998).

As in the Loma Marcelo skarn, the presence of $\mathrm{Al}$ in dolomitic a

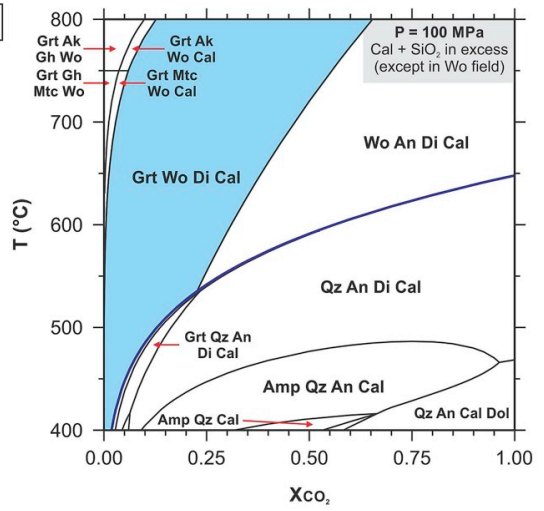

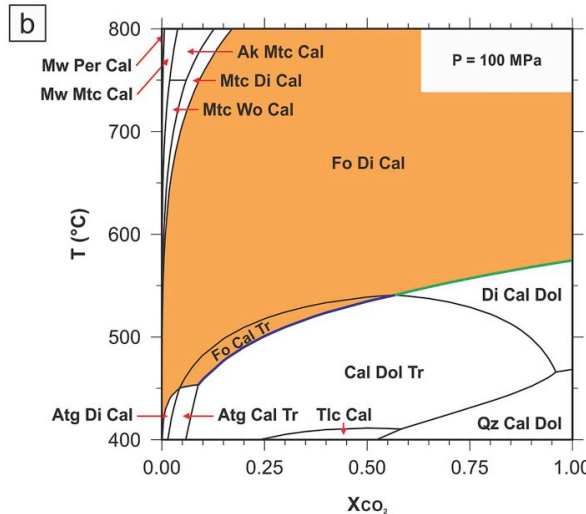

Fig. 11. a) Isobaric $\mathrm{T}-\mathrm{X}_{\mathrm{CO} 2}$ diagram of the $\mathrm{CaO}$ $\mathrm{MgO}-\mathrm{Al}_{2} \mathrm{O}_{3}-\mathrm{SiO}_{2}-\mathrm{H}_{2} \mathrm{O}-\mathrm{CO}_{2}$ (CMAS-HC) system at $100 \mathrm{MPa}$ showing the distribution of stable assemblages during contact metamorphism. Calcite and silica are in excess. Equilibrium of reaction $\mathrm{Cal}+\mathrm{SiO}_{2} \leftrightarrow \mathrm{Wo}+\mathrm{CO}_{2}$ is highlighted in blue. The light blue field corresponds to the stability field of the garnet-diopside-wollastonite-calcite assemblage. The modelled composition was $\mathrm{Si}(100) \mathrm{Al}(2) \mathrm{Mg}(2) \mathrm{Ca}(100) ; \mathrm{H}_{2} \mathrm{O}$ and $\mathrm{CO}_{2}$ were considered in excess. b) Isobaric $\mathrm{T}-\mathrm{X}_{\mathrm{CO} 2}$ diagram of the $\mathrm{CaO}-\mathrm{MgO}-\mathrm{SiO}_{2}-\mathrm{H}_{2} \mathrm{O}-\mathrm{CO}_{2}$ (CMS-HC) system at $100 \mathrm{MPa}$ showing the distribution of stable assemblages during contact metamorphism. Equilibrium reactions 11 $\mathrm{Dol}+\mathrm{Tr} \leftrightarrow 13 \mathrm{Cal}+8 \mathrm{Fo}+9 \mathrm{CO}_{2}+\mathrm{H}_{2} \mathrm{O}$ (blue) and $3 \mathrm{Dol}+\mathrm{Di} \leftrightarrow 4 \mathrm{Cal}+2 \mathrm{Fo}+2 \mathrm{CO}_{2}$ (green) are highlighted. The orange field corresponds to the stability field of forsterite. The modelled composition was $\mathrm{Si}(0.2) \mathrm{Mg}(0.15) \mathrm{Ca}(0.75) ; \mathrm{H}_{2} \mathrm{O}$ and $\mathrm{CO}_{2}$ were considered in excess. Both diagrams were constructed with the Theriak/Domino software developed by De Capitani and Petrakakis (2010) using the internally consistent thermodynamic database based on Berman (1988). Abbreviations: $\mathrm{Ak}=$ akermanite, $\mathrm{Amp}=$ amphibole, $\mathrm{An}=$ anorthite, Atg $=$ antigorite, Cal $=$ calcite, $\mathrm{Di}=$ diopside, $\mathrm{Dol}=$ dolomite, $\mathrm{Fo}=$ forsterite, $\mathrm{Gh}=$ gehlenite, $\mathrm{Grt}=$ grossularitic garnet, $\mathrm{Mtc}=$ monticellite, $\mathrm{Mw}=$ merwinite, Per $=$ periclase, $\mathrm{Qz}=$ quartz, $\mathrm{Tlc}=$ talc, $\mathrm{Tr}=$ tremolite, $\mathrm{Wo}=$ wollastonite. (For interpretation of the references to colour in this figure legend, the reader is referred to the Web version of this article.) 
protoliths can favour the formation of spinel in assemblages with forsterite at high temperatures. Dolomitic limestones and dolostones usually contain variable amounts of Al-bearing minerals like clinochlore, a Mg-chlorite that is stable over a wide range of temperatures, except at high temperatures. In the granulite facies of regional metamorphism and in lowpressure contact aureoles, clinochlore is decomposed by the following spinel-forming reaction: 2 Dolomite + Clinochlore $\leftrightarrow 2$ Calcite +3 Forsterite + Spinel $+2 \mathrm{CO}_{2}+4 \mathrm{H}_{2} \mathrm{O}$ (Bucher-Nurminen, 1982). The reaction has a minimum temperature of $555^{\circ} \mathrm{C}$ at $100 \mathrm{MPa}$ and marks the disappearance of clinochlore in rocks with the assemblage dolomite-clinochlore-forsterite-calcite.

\subsection{Second metamorphic event (M2)}

The circulation of fluids with $\mathrm{F}$ characterized the M2 event, forming high-F vesuvianite, garnet (type 2), and clinopyroxene (type II) in the calcic skarn and high-F chondrodite in the magnesian skarn (Fig. 10).

\subsubsection{Calcic skarn (paragenesis 2)}

The garnet/pyroxene ratio is much higher in the M2 event than in the M1 event. This higher garnet content could be related to the greater availability of $\mathrm{Al}$ during the M2 event. Compared with the composition of type 1 garnet, the more grossularitic composition of type 2 garnet ( $\mathrm{Grs}_{85.64-98.84 \%} \mathrm{Adr}_{0.00-9.04 \%}$ ) would have been favoured by the metasomatic introduction of $\mathrm{F}$ and the consequent increase of Al mobility in hydrothermal fluids through the formation of fluoride complexes (Tagirov et al., 2002a, 2002b). On the other hand, type II clinopyroxene ( $\mathrm{Di}_{63.42-87.27 \%} \mathrm{Hd}_{12.39-35.79 \%}$ ) is more diopsidic than type I clinopyroxene. The greater availability of $\mathrm{Mg}$ allowed the formation of diopsidic clinopyroxene.

The high-F contents detected in vesuvianite from the Loma Marcelo skarn reflect the activity of this element during the M2 event. Vesuvianite was formed from garnet, clinopyroxene, and wollastonite, which were formed during the M1 event, by the reaction 5 Grossular + 3 Diopside + Wollastonite $+5 \mathrm{H}_{2} \mathrm{O} \leftrightarrow$ Vesuvianite +4 Quartz (Bowman, 1998a). The maximum temperature limit for the vesuvianite-quartz assemblage is $390^{\circ} \mathrm{C}$ at $100 \mathrm{MPa}$ (striped field in Fig. 12a). The mineral assemblage resulting from the above reaction can be clearly seen in LM-9 and LM-10 skarn outcrops, where vesuvianite of paragenesis 2 is formed from the minerals that constitute paragenesis 1 (Fig. 6b and c).

Gnos and Armbruster (2006) pointed out the existence of a systematic dependence between the symmetry of the space group and the crystallization temperature of the vesuvianite: $\mathrm{P} 4 / \mathrm{nnc}$ space group is typical of high temperatures $\left(>500^{\circ} \mathrm{C}\right)$, whereas at low temperatures $\mathrm{P} 4 / \mathrm{n}\left(300-500{ }^{\circ} \mathrm{C}\right)$ and $\mathrm{P} 4 \mathrm{nc}\left(<300^{\circ} \mathrm{C}\right)$ space groups dominate. Conventional XRD methods (e.g., powder method) do not allow vesuvianite "polytypes" to be distinguished since the characteristic reflections, typical of low symmetry vesuvianites, are too weak to be registered (Arem and Burnham, 1969; Armbruster and Gnos, 2000a). However, the compositional characteristics of vesuvianites from the Loma Marcelo skarn (e.g., T site vacancies, occupation of the $19 \mathrm{X}$ sites, no excess of cations in $Y$ sites, sum of cations $\approx 50$ c.p.f.u.; Appendix A.5) would allow them to be assigned to a low symmetry space group (Gnos and Armbruster, 2006). On the other hand, high-F content could promote the formation of high symmetry vesuvianite at low temperature. Galuskin et al. (2003) pointed out that the existence of high symmetry vesuvianites formed at low temperatures $\left(<350{ }^{\circ} \mathrm{C}\right)$ is not only determined by the temperature but also by the composition of the fluid phase and by the crystal growth regime. It should be noted that vesuvianites of low symmetry do not contain significant amounts of $\mathrm{F}$ (e.g., Fitzgerald et al., 1992; Ohkawa et al., 1994; Armbruster and Gnos, 2000a, 2000b). Petrographical and compositional similarities between different types of vesuvianite identified in the Loma Marcelo skarn suggest that they were formed during the same metamorphic event.

Titanite of the calcic skarn presents compositional zoning, with lowF cores $(1.73 \%)$ and enriched rims (2.12-2.47\%), indicating the existence of two retrograde stages related to fluids with different $\mathrm{F}$ content: the first one related to the M1 event (low-F) and the second one to the M2 event (high-F) (Ballivián Justiniano et al., 2017). This fact would confirm that high-F contents were introduced sometime after the M1 event, possibly during the M2 event.

\subsubsection{Magnesian skarn}

Chondrodite from the Loma Marcelo skarn has high-F contents $\left(\mathrm{X}_{\mathrm{F}}{ }^{\mathrm{Chn}}=0.75\right)$ and petrographic evidence suggests that it was formed as a chondrodite pseudomorph after forsterite. The observed assemblage is chondrodite-calcite-forsterite. A possible reaction is 2

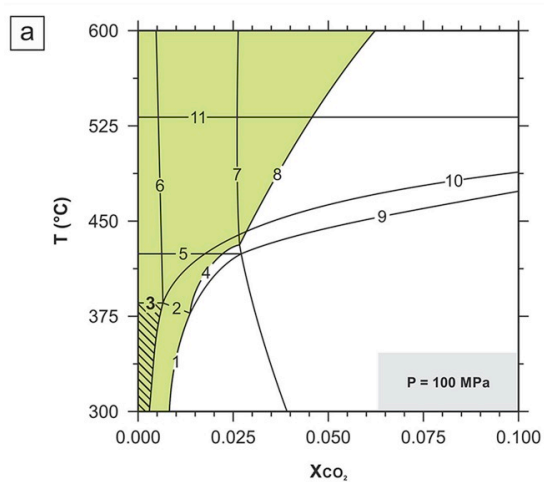

Reactions

1) $2 \mathrm{CzO}+5 \mathrm{Cal}+3 \mathrm{Qz}=3 \mathrm{Grs}+5 \mathrm{CO}_{2}+\mathrm{H}_{2} \mathrm{O}$

2) $\mathrm{Ves}+6 \mathrm{Qz}+4 \mathrm{CO}_{2}=2 \mathrm{Grs}+9 \mathrm{Di}+4 \mathrm{Cal}+5 \mathrm{H}_{2} \mathrm{O}$

3) $\mathrm{Ves}+7 \mathrm{Qz}+3 \mathrm{CO}_{2}=2 \mathrm{Grs}+9 \mathrm{Di}+\mathrm{Wo}+3 \mathrm{Cal}+5 \mathrm{H}_{2} \mathrm{O}$

4) $3 \mathrm{Ves}+14 \mathrm{CO}_{2}=9 \mathrm{Grs}+6 \mathrm{Di}+5 \mathrm{CzO}+14 \mathrm{Cal}+11 \mathrm{H}_{2} \mathrm{O}$

5) $4 \mathrm{CzO}+\mathrm{Qz}=\mathrm{Grs}+5 \mathrm{An}+2 \mathrm{H}_{2} \mathrm{O}$

6) $2 \mathrm{Ves}+5 \mathrm{Wo}+6 \mathrm{CO}_{2}=11 \mathrm{Grs}+4 \mathrm{Di}+6 \mathrm{Cal}+9 \mathrm{H}_{2} \mathrm{O}$

7) $3 \mathrm{CzO}+\mathrm{CO}_{2}=3 \mathrm{An}+\mathrm{Cal}+\mathrm{H}_{2} \mathrm{O}$

8) $2 \mathrm{Ves}+11 \mathrm{CO}_{2}=6 \mathrm{Grs}+4 \mathrm{Di}+5 \mathrm{An}+11 \mathrm{Cal}+9 \mathrm{H}_{2} \mathrm{O}$

9) $\mathrm{An}+2 \mathrm{Cal}+\mathrm{Qz}=\mathrm{Grs}+2 \mathrm{CO}_{2}$

10) $\mathrm{Cal}+\mathrm{Qz}=\mathrm{Wo}+\mathrm{CO}_{2}$

11) $\mathrm{Grs}+\mathrm{Qz}=\mathrm{An}+2 \mathrm{Wo}^{2}$

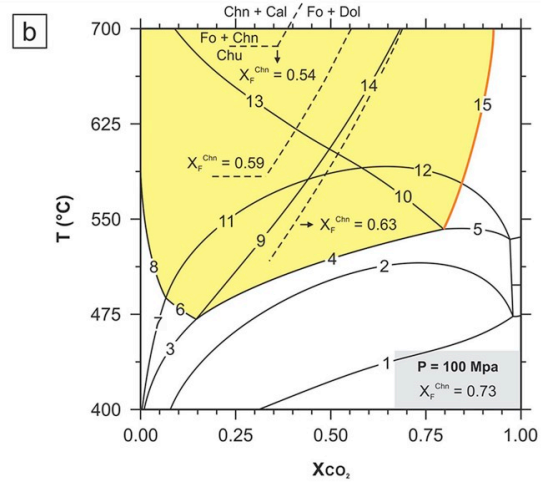

Reactions

1) $5 \mathrm{Dol}+8 \mathrm{Qz}+\mathrm{H}_{2} \mathrm{O}=\mathrm{Tr}+3 \mathrm{Cal}+7 \mathrm{CO}_{2}$

2) $\mathrm{Tr}+3 \mathrm{Cal}+\mathrm{Qz}=5 \mathrm{Di}+3 \mathrm{CO}_{2}+\mathrm{H}_{2} \mathrm{O}$

3) $\mathrm{Tr}+19 \mathrm{Dol}+7 \mathrm{H}_{2} \mathrm{O}=8 \mathrm{Nrb}+21 \mathrm{Cal}+17 \mathrm{CO}$

4) $\mathrm{Tr}+15 \mathrm{Dol}+3 \mathrm{H}_{2} \mathrm{O}=4 \mathrm{Chn}+17 \mathrm{Cal}+13 \mathrm{CO}_{2}$

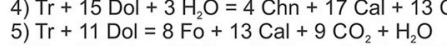

6) $\mathrm{Tr}+30 \mathrm{Nrb}+2 \mathrm{CO}_{2}=19 \mathrm{Chn}+2 \mathrm{Cal}+12 \mathrm{H}_{2} \mathrm{O}$

7) $5 \mathrm{Tr}+9 \mathrm{Cal}=19 \mathrm{Di}+2 \mathrm{Nrb}+9 \mathrm{CO}_{2}+3 \mathrm{H}_{2} \mathrm{O}$

8) $\mathrm{Di}+8 \mathrm{Nrb}+\mathrm{CO}_{2}=5 \mathrm{Chn}+\mathrm{Cal}+3 \mathrm{H}_{2} \mathrm{O}$

9) $\mathrm{Dol}+\mathrm{Chn}+\mathrm{H}_{2} \mathrm{O}=2 \mathrm{Nrb}+\mathrm{Cal}+\mathrm{CO}_{2}$

10) $\mathrm{Tr}+11 \mathrm{Chn}+2 \mathrm{CO}_{2}=30 \mathrm{Fo}+2 \mathrm{Cal}+12 \mathrm{H}_{2} \mathrm{O}$

11) $4 \mathrm{Tr}+7 \mathrm{Cal}=15 \mathrm{Di}+\mathrm{Chn}+7 \mathrm{CO}_{2}+3 \mathrm{H}_{2} \mathrm{O}$

12) $3 \mathrm{Tr}+5 \mathrm{Cal}=11 \mathrm{Di}+2 \mathrm{Fo}+5 \mathrm{CO}_{2}+3 \mathrm{H}_{2} \mathrm{O}$

13) $\mathrm{Di}+3 \mathrm{Chn}+\mathrm{CO}_{2}=8 \mathrm{Fo}+\mathrm{Cal}+3 \mathrm{H}_{2} \mathrm{O}$

14) $\mathrm{Di}+3 \mathrm{Chn}+\mathrm{CO}_{2}=8 \mathrm{Fo}+\mathrm{Cal}+3 \mathrm{H}_{2} \mathrm{O}$

15) $2 \mathrm{Fo}+\mathrm{Dol}+\mathrm{H}_{2} \mathrm{O}=\mathrm{Chn}+\mathrm{Cal}+\mathrm{CO}_{2}$
15
Fig. 12. a) Isobaric $\mathrm{T}-\mathrm{X}_{\mathrm{CO} 2}$ diagram of the aqueous portion $\left(\mathrm{X}_{\mathrm{CO} 2}=0.0-0.1\right)$ of the $\mathrm{CaO}-\mathrm{MgO}-\mathrm{Al}_{2} \mathrm{O}_{3}-\mathrm{SiO}_{2}-\mathrm{H}_{2} \mathrm{O}$ $\mathrm{CO}_{2}$ (CMAS-HC) system at $100 \mathrm{MPa}$ (modified from Bowman, 1998a). The green field corresponds to the stability field of the grossular-vesuvianite assemblage. The striped field corresponds to the stability field of the vesuvianite-quartz assemblage formed from the grossular-diopside-wollastonite assemblage $\left(\mathrm{T}<390^{\circ} \mathrm{C}\right)$. Abbreviations: $\mathrm{An}=$ anorthite, $\mathrm{Cal}=$ calcite, $\mathrm{Czo}=$ clinozoisite, $\mathrm{Di}=$ diopside, $\mathrm{Grs}=$ grossular, $\mathrm{Qz}=$ quartz, Ves $=$ vesuvianite, $\quad$ Wo $=$ wollastonite. b) Isobaric $\mathrm{T}-\mathrm{X}_{\mathrm{CO} 2}$ diagram of the $\mathrm{CaO}-\mathrm{MgO}-\mathrm{SiO}_{2}-\mathrm{H}_{2} \mathrm{O}-\mathrm{CO}_{2}-\mathrm{HF}$ (CMS-HCF) system at $100 \mathrm{MPa}$ and $\mathrm{X}_{\mathrm{F}}{ }^{\mathrm{Chn}}=0.73$ (modified from Rice, 1980a). Equilibrium of reaction 2 $\mathrm{Fo}+\mathrm{Dol}+\mathrm{H}_{2} \mathrm{O} \leftrightarrow \mathrm{Chn}+\mathrm{Cal}+\mathrm{CO}_{2}(15)$ is highlighted in orange. Dashed curves correspond to reaction 15 for different values of $\mathrm{X}_{\mathrm{F}}{ }^{\mathrm{Chn}}$. The yellow field corresponds to the stability field of chondrodite. Abbreviations: $\mathrm{Cal}=$ calcite, $\mathrm{Chn}=$ chondrodite, $\mathrm{Chu}=$ clinohumite Di $=$ diopside,$\quad$ Dol $=$ dolomite,$\quad$ Fo $=$ forsterite, $\mathrm{Nbg}=$ norbergite, $\mathrm{Qz}=$ quartz, $\mathrm{Tr}=$ tremolite. (For interpretation of the references to colour in this figure legend, the reader is referred to the Web version of this article.) 
Forsterite + Dolomite $+\mathrm{H}_{2} \mathrm{O} \leftrightarrow$ Chondrodite + Calcite $+\mathrm{CO}_{2}$ (Fig. 12b). This equilibrium reaction extends from temperatures above $685^{\circ} \mathrm{C}$ at $\mathrm{X}_{\mathrm{CO} 2}=0.36$ for $\mathrm{X}_{\mathrm{F}}^{\mathrm{Chn}}=0.54$ to temperatures as low as $517{ }^{\circ} \mathrm{C}$ at $\mathrm{X}_{\mathrm{CO} 2}=0.34$ for $\mathrm{X}_{\mathrm{F}}^{\mathrm{Chn}}=0.63$. However, for values of $\mathrm{X}_{\mathrm{F}}^{\mathrm{Chn}} \approx 0.7$, as determined in the Loma Marcelo skarn chondrodite, the previous equilibrium reaction extends from about $540{ }^{\circ} \mathrm{C}$ and $\mathrm{X}_{\mathrm{CO} 2}=0.8$ to above $700{ }^{\circ} \mathrm{C}$ and $\mathrm{X}_{\mathrm{CO} 2}>0.9$ (Fig. 12b). The possible predominance of $\mathrm{CO}_{2}$-rich conditions during the formation of chondrodite in the magnesian skarn contrasts with the $\mathrm{H}_{2} \mathrm{O}$-rich conditions estimated during the formation of vesuvianite in the calcic skarn. On the $\mathrm{H}_{2} \mathrm{O}$-rich side of the isobaric $\mathrm{T}-\mathrm{X}_{\mathrm{CO} 2}$ diagram of Fig. $12 \mathrm{~b}$, the chondrodite-calcite assemblage may be the result of reactions 4,6 , and 8 involving dolomite, tremolite, and norbergite as reactants.

Petrographic evidence also suggests that chondrodite would have been formed from dolomite. The metasomatic introduction of silica by aqueous fluids could also promote the formation of chondrodite from forsterite and even from dolomite. The possible reactions are the following:

Forsterite +3 Dolomite $+\mathrm{SiO}_{2}+\mathrm{H}_{2} \mathrm{O} \leftrightarrow$ Chondrodite +3 Calcite + $3 \mathrm{CO}_{2}$

5 Dolomite $+2 \mathrm{SiO}_{2}+\mathrm{H}_{2} \mathrm{O} \leftrightarrow$ Chondrodite +5 Calcite $+5 \mathrm{CO}_{2}$

However, the phase equilibria that govern the stability of chondrodite under the aforementioned conditions require further investigation.

Rice (1980a) and Piazolo and Markl (1999) pointed out that the humite-group minerals can be formed in impure metamorphosed carbonates during metasomatism, involving the introduction of $\mathrm{F}$ and its reaction with the pre-existing minerals. At low pressures, humite-group minerals do not require unusual temperatures or fluid compositions to be stable in metamorphosed carbonate rocks, with the availability of $\mathrm{F}$ in the protolith and/or in metasomatic fluids being the most important factor determining their occurrence (Rice, 1980a, 1980b). In this regard, hydrothermal reactions can result in the formation of minerals under metastable conditions, especially if the fluids are chemically reactive.

Dozyite from the Loma Marcelo skarn could have been formed during a retrograde metamorphism related to the M2 event. The low contents of $\mathrm{F}$ suggest its formation from late fluids with very low halogens content or some restriction regarding the incorporation of $\mathrm{F}$ in dozyite structure. Bailey et al. (1995) inferred from textural relationships that dozyite from the Ertsberg East mine was formed by direct replacement of pre-existing chlorite and that dozyite was then replaced by serpentine (chlorite $\rightarrow$ dozyite $\rightarrow$ serpentine). According to this, clinochlore could be the first product of the progressive alteration of chondrodite from the Loma Marcelo skarn.

\subsection{Third metamorphic event (M3)}

Epidotization and serpentinization processes identified in the calcic and magnesian skarns, respectively, could be attributed to the M3 event (Fig. 10). Type 3 garnet ( $\mathrm{Grs}_{95.17-99.82 \%} \mathrm{Adr}_{0.00-4.67 \%}$ ) was formed in the calcic skarn (Fig. 10) by static crystallization processes and is interpreted as post-tectonic due to the absence of deformational features in relation to the D1 deformation event, which is synchronous with the M3 event. Boudins would also be structures related to D1. In some sectors, grossular formed masses that replaced great portions of the calcic skarn (e.g., LM-4 and LM-10) or formed rims around some skarn bodies (e.g., LM-9), whereas in other sectors, it remained restricted to small cavities.

\section{LA-ICP-MS $\mathrm{U}-\mathrm{Pb}$ zircon dating of the Loma Marcelo granite}

A single zircon from the calcic skarn defined an LA-ICP-MS U-Pb upper intercept age of $648 \pm 21$ Ma (Ballivián Justiniano et al., 2017), providing the maximum sedimentation age for the calcic protolith of the Loma Marcelo skarn. The SHRIMP U-Pb crystallization age of $607.0 \pm 5.2$ Ma determined by Rapela et al. (2003) for the Cerro del Corral Granite was initially considered by Ballivián Justiniano et al. (2017) as the minimum sedimentation age of the Loma Marcelo skarn protoliths. In order to accurately constraint the minimum sedimentation age of these protoliths, an LA-ICP-MS U-Pb zircon dating of the Loma Marcelo Granite (Fig. 13a) was performed.

The selected zircon grains can be divided into two main groups: a) irregular to sub-rounded grains, some of them poly-faceted, $100-212 \mu \mathrm{m}$ long, $100-178 \mu \mathrm{m}$ wide, and aspect ratios of $0.6-1.0$ and b) prismatic grains, some of them dipyramidal, $118-230 \mu \mathrm{m}$ long, 66-120 $\mu \mathrm{m}$ wide, and aspect ratios of 0.4-0.6. All grains are translucent and colourless or reddish brown, amber, or light pink. The cathodoluminescence images show homogeneous unzoned zircons, as well as zircons with growth zoning, xenocrystalline cores, and/or newly
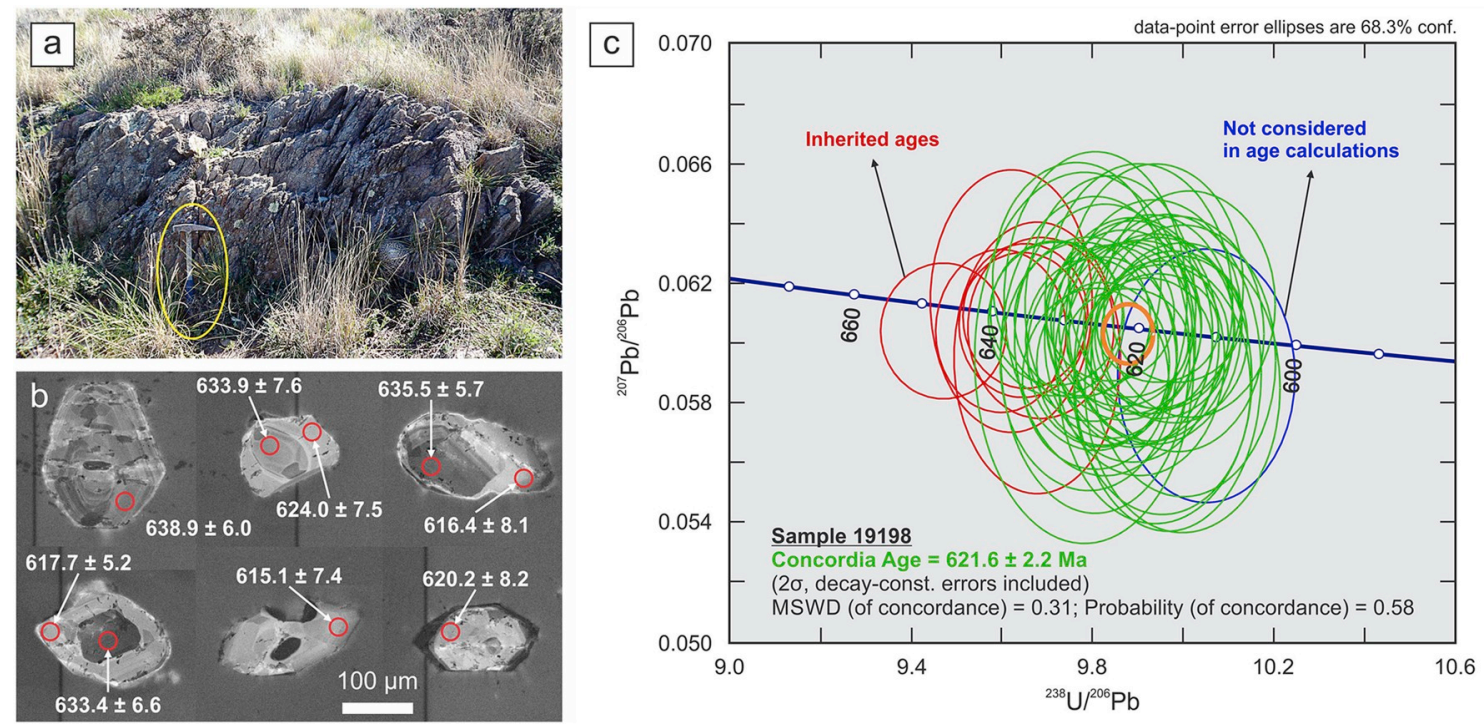

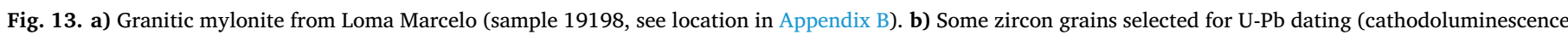

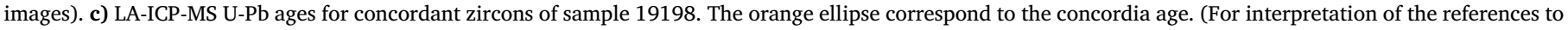
colour in this figure legend, the reader is referred to the Web version of this article.) 
grown rims. Some of the analysed zircon grains are shown in Fig. 13b.

Forty-seven zircon grains from the Loma Marcelo Granite were analysed (Appendix B). The best estimate U-Pb concordia age for the crystallization of the Loma Marcelo Granite (39 spots) is $621.6 \pm 2.2 \mathrm{Ma}$ with MSWD $=0.31$ (Fig. 13c). This concordia age is very similar to that of $621.0 \pm 2.3 \mathrm{Ma}(\mathrm{MSWD}=1.3)$ obtained for the Loma Marcelo Granite by Ballivián Justiniano et al. (under review). Spots with ${ }^{206} \mathrm{~Pb} /{ }^{238} \mathrm{U}$ ages of $c a .611 \mathrm{Ma}$ and $c a .633-647$ Ma were not considered in calculations. Ages older than $c a$. 631 Ma could be considered as corresponding to inherited zircons, whereas the age of $c a$. $611 \mathrm{Ma}$ could correspond to metamorphism or $\mathrm{Pb}$ loss. The youngest and oldest ages obtained are 611.4 Ma and 647.1 Ma, respectively. Approximately $83 \%$ of the 47 spots are between ca. 614 and ca. $631 \mathrm{Ma}$. Three ages between $c a .633$ and $c a$. 636 Ma were obtained in the core of zircons whose rims yielded ages between $c a .616$ and $c a$. 624 Ma.

The U-Pb age presented here for the Loma Marcelo Granite allows reassigning the minimum sedimentation age of the skarn protoliths to ca. $622 \mathrm{Ma}$, constraining the age of the calcic skarn protolith from $c a$. 648 Ma to ca. 622 Ma.

\section{8. $\mathrm{C}$ and $\mathrm{O}$ stable isotopes in carbonates from the Loma Marcelo skarn}

Measurements of $\mathrm{C}$ and $\mathrm{O}$ stable isotopes in carbonate minerals from the Loma Marcelo skarn are listed in Table 2 and plotted in Fig. 14. Calcite from the calcic skarn have $\delta^{13} \mathrm{C}$ values between -10.1 and $-2.6 \%$ and $\delta^{18} \mathrm{O}$ values between +7.3 and $+14.0 \%$. Calcite and dolomite from the magnesian skarn have $\delta^{13} \mathrm{C}$ values between -2.8 and $-2.6 \%$ and $\delta^{18} \mathrm{O}$ values between +11.5 and $+13.7 \%$. These results show similar values for $\delta^{13} \mathrm{C}$ in carbonates from both types of skarn and higher values of $\delta^{18} \mathrm{O}$ in the magnesian skarn than in the calcic skarn. It should be noted that samples from LM-4 and LM-10 skarn outcrops have anomalous values, as the calcite is much depleted in ${ }^{13} \mathrm{C} \quad\left(\delta^{13} \mathrm{C}=-8.0 /-10.1 \% 0\right)$ and much enriched in ${ }^{18} \mathrm{O}$ $\left(\delta^{18} \mathrm{O}=+13.6 /+14.0 \%\right)$. Additionally, values of $\delta^{13} \mathrm{C}=-3.0 \%$ and $\delta^{18} \mathrm{O}=+7.6 \%$ were determined in a calcite sample from a quartz \pm calcite vein that post-tectonically cuts the already mylonitized granites of Cerro 21 de Septiembre (Table 2); these values are in the range of those of the Loma Marcelo skarn.

Relative to $\delta^{13} \mathrm{C}$ and $\delta^{18} \mathrm{O}$ values common in marine limestones $\left(\delta^{13} \mathrm{C}=0.0 /+3.5 \%\right.$ and $\delta^{18} \mathrm{O}=+5.0 /+25.0 \%$; Bowman, 1998b) carbonates from the Loma Marcelo skarn are depleted in the heavy isotopes. Additionally, the obtained results plot within the carbonatite field defined by Deines (1989) $\left(\delta^{13} \mathrm{C}=-8.0 /-2.0 \%\right.$ and $\delta^{18} \mathrm{O}=+2.0 /+25.0 \%$; Fig. 14a). However, similar values can be found in skarns derived from sedimentary or metasedimentary carbonate protoliths where variations in the environmental physical conditions, decarbonation reactions, fluid-rock interactions, and/or fluid mixing took place (Bowman, 1998b; Baumgartner and Valley, 2001).

The $\delta^{13} \mathrm{C}$ and $\delta^{18} \mathrm{O}$ values of carbonates are sensitive to decarbonation reactions, external fluid-rock interaction, and isotope exchange reactions (Valley, 1986). The isotopic depletion pattern of the Loma Marcelo skarn is consistent with that observed in many contact aureoles and in most skarns worldwide (Bowman, 1998b). Decarbonation reactions sometimes can explain the ${ }^{13} \mathrm{C}$ and ${ }^{18} \mathrm{O}$ depletions resulting from contact metamorphism and metasomatism.

As shown in Fig. 14a, batch volatilization and Rayleigh distillation do not satisfactorily explain the large ${ }^{18} \mathrm{O}$ depletion observed in the Loma Marcelo skarn. The effect of decarbonation reactions on $\delta^{18} \mathrm{O}$ depletions in carbonate rocks is small because the mole fraction of oxygen is high $\left(\mathrm{F}_{\mathrm{O}}>0.6\right)$, even if decarbonation is complete. On the other hand, the effect of decarbonation reactions on $\delta^{13} \mathrm{C}$ values would be much greater, with the molar fraction of carbon $\left(\mathrm{F}_{\mathrm{C}}\right)$ reaching as low as zero. When this is the case, $\mathrm{F}_{\mathrm{O}}=0.60$ (the calc-silicate limit; Valley, 1986) and all the carbonate minerals of the rock are replaced by calcsilicate minerals. Even under these conditions, the calculated values of $\delta^{18} \mathrm{O}$ and $\delta^{13} \mathrm{C}$ would not agree with those observed in the Loma Marcelo skarn since the ${ }^{18} \mathrm{O}$ depletion would be small.

The Loma Marcelo skarn is enriched in ${ }^{13} \mathrm{C}$ in relation to magmatic fluids $\left(\delta^{13} \mathrm{C}=-8.0 /-5.0 \%\right.$; Bowman, 1998b), so its carbon isotopic composition must have been affected by the ${ }^{13} \mathrm{C}$ of the carbonate protolith. Variations in $\delta^{13} \mathrm{C}$ values are usually attributed to the oxidation state and the reaction of metasomatic fluids with carbonate protoliths (Shimazaki et al., 1986). When the water/rock ratio is low, the C content of the fluid is negligible compared to its $\mathrm{O}$ content and the $\mathrm{O}$ content of the carbonate is rapidly modified without substantial variations in its $\mathrm{C}$ composition (since there is much $\mathrm{C}$ in the carbonate and very little in the water). As the mineral interacts more and more with the fluid, the $\mathrm{O}$ value of the carbonate will be completely modified by the $\mathrm{O}$ value of the fluid. Only when the water/rock ratio is very high, the $\mathrm{C}$ content of the mineral will be modified without large additional variations in its $\mathrm{O}$ composition.

The lower $\delta^{18} \mathrm{O}$ values of the Loma Marcelo skarn are those of the calcic skarn and, like those corresponding to the magnesian skarn, they are more similar to the $\delta^{18} \mathrm{O}$ values determined for granitic intrusions adjacent to numerous skarns $\left(\delta^{18} \mathrm{O}=+7.5 /+12.0 \%\right.$; Bowman, 1998b) than those of marine limestones (Fig. 14a). The variation of the $\delta^{13} \mathrm{C}$ and $\delta^{18} \mathrm{O}$ values in carbonates from the Loma Marcelo skarn can only be explained by the water-rock interaction between magmatic fluids and marine carbonates.

The equations for the mass balance given below are those of Taylor (1977) and were used to model the isotopic variations in carbonates from the Loma Marcelo skarn:

$$
\begin{aligned}
& \delta^{18} O_{\text {rock }(f)}=\frac{\delta^{18} O_{\text {rock }(i)}+\left(W / R \times \delta^{18} O_{\text {fluid }(i)}\right)+\left(W / R \times \Delta_{\text {cal }-\mathrm{H} 2 O}\right)}{1+W / R} \\
& \delta^{13} C_{\text {rock }(f)}=\frac{\delta^{13} C_{\text {rock }(i)}+\left(X_{\mathrm{CO} 2} \times W / R \times \delta^{13} C_{f l u i d}(i)\right)+\left(X_{\mathrm{CO} 2} \times W / R \times \Delta_{\text {cal }-\mathrm{CO} 2}\right)}{1+W / R}
\end{aligned}
$$

where $\delta_{\text {rock(f) }}$ and $\delta_{\text {rock(i) }}$ are the final and initial isotopic compositions of the carbonate protolith, respectively, $\delta_{\text {fluid(i) }}$ is the initial isotopic composition of the metasomatic fluid, $\mathrm{W} / \mathrm{R}$ is the water/rock ratio, $\Delta$ is the isotopic fractionation factor between the carbonate mineral and the $\mathrm{H}_{2} \mathrm{O}$ or $\mathrm{CO}_{2}$, and $\mathrm{X}_{\mathrm{CO} 2}$ is the molar fraction of $\mathrm{CO}_{2}$. Equations (1) and (2) describe a closed system in which all the fluid is balanced with the rock and the isotopic exchange is dependent on the temperature and the $\mathrm{W} / \mathrm{R}$ ratio. Isotopic exchange between fluids and adjacent rocks can also be modelled in an open system using the following equation of Taylor (1977): $(\mathrm{W} / \mathrm{R})_{\mathrm{os}}=\ln \left[(\mathrm{W} / \mathrm{R})_{\mathrm{cs}}+1\right]$, where the "cs" and "os"

Table 2

Stable isotopes of carbon and oxygen (\%) in carbonates from the Loma Marcelo skarn and a quartz \pm calcite vein that cuts the mylonitic granites of Cerro 21

\begin{tabular}{|c|c|c|c|c|c|}
\hline \multicolumn{2}{|l|}{ Location } & \multirow{2}{*}{$\frac{\text { Sample }}{11412 c-3^{*}}$} & \multirow{2}{*}{$\begin{array}{c}\text { Mineral } \\
\text { Calcite }\end{array}$} & \multirow{2}{*}{$\frac{\delta^{13} \mathrm{C}_{\mathrm{V}-\mathrm{PDB}}}{-8.0}$} & \multirow{2}{*}{$\frac{\delta^{18} \mathrm{O}_{\mathrm{V}-\mathrm{SMOW}}}{13.6}$} \\
\hline Calcic skarn & LM-4 & & & & \\
\hline & LM-9a & $19223-3^{*}$ & Calcite & -2.9 & 9.3 \\
\hline & LM-9b & $11415 a^{* *}$ & Calcite & -2.9 & 9.1 \\
\hline & & $11415 b^{* *}$ & Calcite & -3.2 & 8.6 \\
\hline & & $19177 a^{* *}$ & Calcite & -2.7 & 9.8 \\
\hline & & $19178-1^{*}$ & Calcite & -2.7 & 9.7 \\
\hline & LM-10 & $19241-5^{*}$ & Calcite & -10.1 & 14.0 \\
\hline & LM-13 & $19197-4^{*}$ & Calcite & -2.6 & 7.3 \\
\hline & & $19197-5^{*}$ & Calcite & -3.1 & 9.0 \\
\hline \multirow[t]{5}{*}{ Magnesian skarn } & LM-6 & $11414 a-1^{* *}$ & Calcite & -2.8 & 12.1 \\
\hline & & $11414 a-2^{* *}$ & Dolomite & -2.6 & 13.6 \\
\hline & & $11414 b^{* *}$ & Dolomite & -2.7 & 11.5 \\
\hline & & $19171-1^{*}$ & Calcite & -2.6 & 12.0 \\
\hline & & $19171-2^{*}$ & Dolomite & -2.8 & 13.7 \\
\hline \multirow{2}{*}{\multicolumn{2}{|c|}{ Cerro 21 de Septiembre }} & C21-1* & Calcite & -3.0 & 7.6 \\
\hline & & $\mathrm{C} 21-2 *$ & Quartz & - & 9.1 \\
\hline
\end{tabular}
de Septiembre (the isotopic composition of quartz is also included).

* = this work. ** = data from Ballivián Justiniano et al. (2015). 

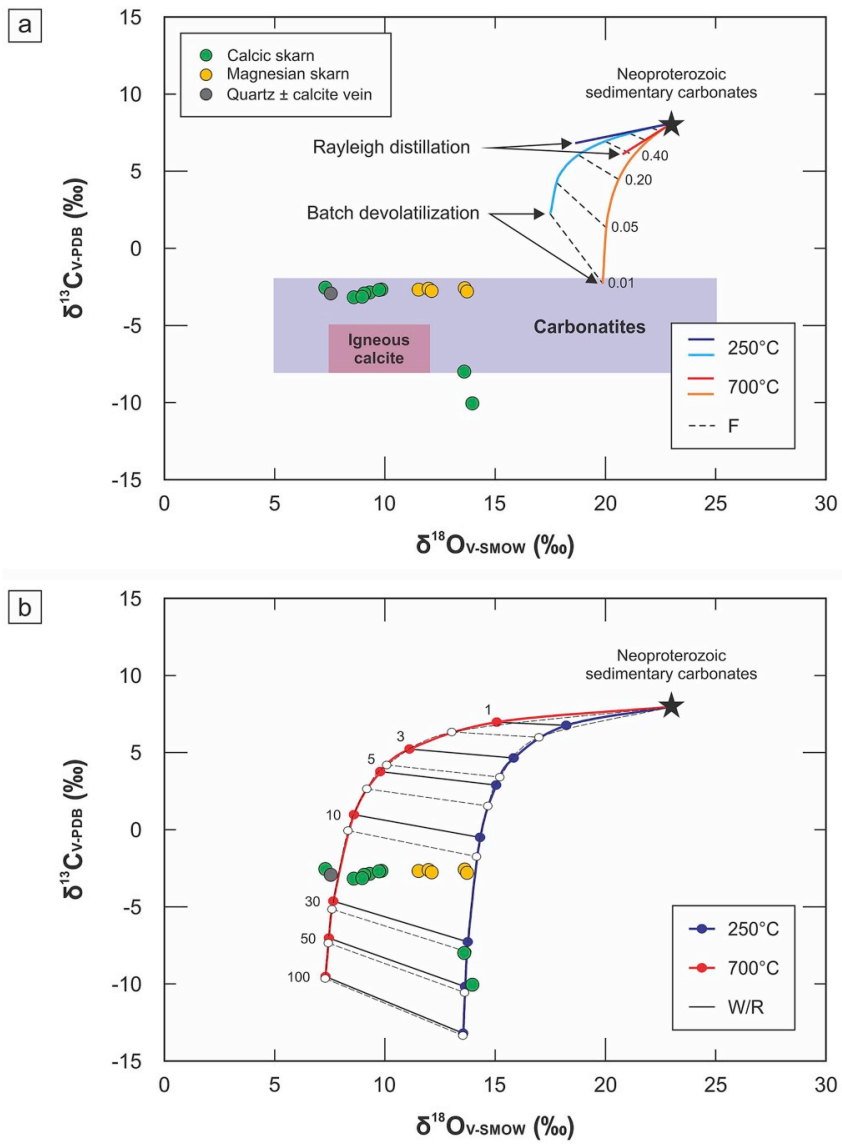

Fig. 14. $\mathrm{C}$ and $\mathrm{O}$ stable isotopes in carbonates from the Loma Marcelo skarn and a quartz \pm calcite vein that cuts the mylonitic granites of Cerro 21 de Septiembre. a) The field of carbonatites is from Deines (1989), and the field of igneous calcite corresponds to calcite in equilibrium with normal magmatic carbon $\left(\delta^{13} \mathrm{C}=-8.0 /-5.0 \%\right.$ ) and the measured values of $\delta^{18} \mathrm{O}$ of the granites adjacent to numerous skarns (Bowman, 1998b). Curves correspond to those calculated for batch volatilization (graduated in increments of the carbon mole fraction, F) and Rayleigh distillation. b) Water-rock interaction curves that describe the isotopic variations of carbon and oxygen in the calcic skarn carbonates resulting from the interaction of magmatic fluids $\left(\delta^{13} \mathrm{C}=-8.0 \%\right.$ and $\delta^{18} \mathrm{O}=+6.0 \%$ ) with a Neoproterozoic sedimentary protolith $\left(\delta^{13} \mathrm{C}=+8.0 \%\right.$ o and $\delta^{18} \mathrm{O}=+23.0 \%$, see Fig. 15). Solid and dashed curves correspond to the closed and open systems, respectively.

subscripts indicate a closed and open system, respectively, and (W/R) os is the value obtained from the $\mathrm{W} / \mathrm{R}$ ratio of the closed system $\left[(\mathrm{W} / \mathrm{R})_{\mathrm{cs}}\right]$. This equation can be used for both carbon and oxygen.

Since the carbonate protoliths of the Loma Marcelo skarn do not crop out and are unknown, the initial isotopic composition of the carbonate protolith used here for the mass balance model is that determined by Jacobsen and Kaufman (1999) for carbonate sedimentary rocks of Neoproterozoic age $\left(\delta^{13} \mathrm{C}_{730-600 \mathrm{Ma}}=+8.0 \%\right.$ and $\delta^{18} \mathrm{O}_{730-600 \mathrm{Ma}}=+23.6 \%$; Fig. 15). This initial composition was also used in the modelling of Rayleigh distillation and batch devolatilization for the Loma Marcelo skarn (Fig. 14a). The isotopic composition assumed as initial is based on the sedimentation age interval of $c a$. 648-622 Ma determined for the calcic protolith of the Loma Marcelo skarn (Ballivián Justiniano et al., 2017; this work). The mass balance model was applied to simulate the effects of isotopic exchange between a carbonate protolith with the indicated composition and a metasomatic fluid with $\delta^{13} \mathrm{C}=-8.0 \%$ and $\delta^{18} \mathrm{O}=+6.0 \%$ at temperatures between 700 and $250{ }^{\circ} \mathrm{C}$ and $\mathrm{X}_{\mathrm{CO} 2}=0.05$. The isotopic composition of the fluid phase is that of calcite in equilibrium with normal magmatic carbon, with values of $\delta^{18} \mathrm{O}$ determined from granitic intrusions adjacent to numerous skarns (Bowman, 1998b). The maximum temperature of $700^{\circ} \mathrm{C}$ is that around which granitic magmas crystallize. The minimum temperature of $250{ }^{\circ} \mathrm{C}$ is based on the isotope equilibrium temperature calculated for the calcite-quartz pair (Zheng, 1993) from a quartz \pm calcite vein that post-tectonically cuts the already mylonitized granites of Cerro 21 de Septiembre $\left(\delta^{18} \mathrm{O}_{\mathrm{Cal}}=+7.6 \%\right.$ and $\delta^{18} \mathrm{O}_{\mathrm{Qz}}=+9.1 \%$; Table 2 ). The model considers only the maximum and minimum temperatures during the prograde metamorphism (M1 and M3 events, respectively; see below). The presence of wollastonite and vesuvianite in the Loma Marcelo skarn justifies the use of $\mathrm{X}_{\mathrm{CO} 2}=0.05$. Several authors consider that the formation of these minerals in calc-silicate rocks requires essentially aqueous fluids (Trommsdorff, 1968; Hochella et al., 1982; Rice, 1983; Valley et al., 1985). The isotopic fractionation factors of Zheng (1999) were used in calculations.

$\delta^{13} \mathrm{C}-\delta^{18} \mathrm{O}$ variation curves were calculated for both calcic (Fig. 14b) and magnesian (not shown) skarns. The curves of both skarns are very similar to each other and the isotopic carbon and oxygen determinations fit them well. Fig. $14 \mathrm{~b}$ is the result of the mutual interaction between magmatic fluids and carbonate protoliths. Consequently, the ${ }^{13} \mathrm{C}$ and ${ }^{18} \mathrm{O}$ depletions in carbonates from the Loma Marcelo skarn can be interpreted as resulting from the interaction of magmatic fluids with Neoproterozoic carbonate sedimentary rocks in the temperature range between 700 and $250^{\circ} \mathrm{C}$. Most isotopic determinations are between the lines that represent $\mathrm{W} / \mathrm{R}$ ratios from 10 to 30. In Fig. $14 \mathrm{~b}, \delta^{13} \mathrm{C}-\delta^{18} \mathrm{O}$ variation curves for an open system (dashed lines) are very similar to those calculated for a closed system (solid lines).

\section{Discussion}

\subsection{Origin of the Loma Marcelo skarn protoliths}

During its ascent and emplacement, the Loma Marcelo Granite incorporated xenoliths of carbonate rocks of calcic and magnesian composition, forming calcic and magnesian skarns, respectively. The presence of xenoliths suggests that the granite outcrop (Fig. 1c) corresponds to the upper levels close to the roof of the intrusive body, since xenoliths are rare or do not exist at the deepest levels (Llambías,

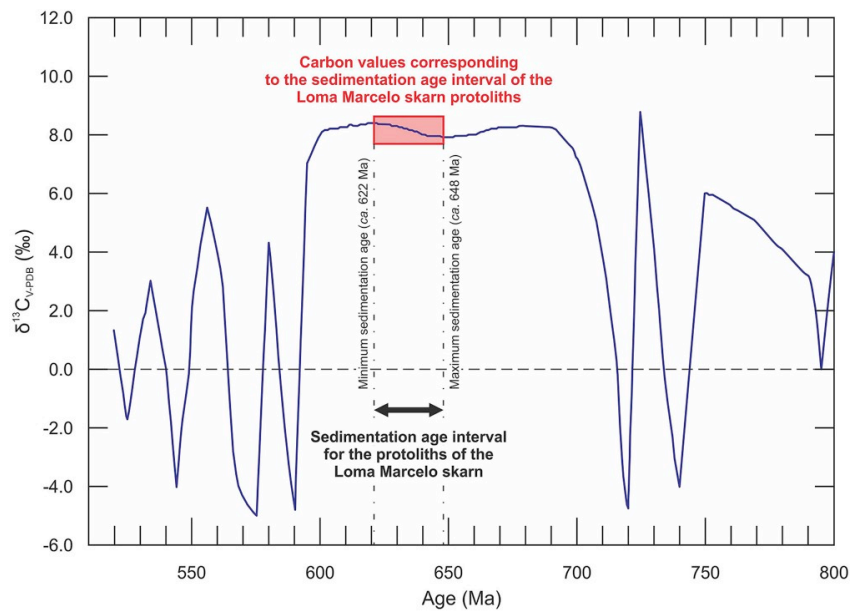

Fig. 15. Temporal variations in $\delta^{13} \mathrm{C}$ of Neoproterozoic carbonates (modified from Jacobsen and Kaufman, 1999). The figure shows the minimum and maximum sedimentation ages of the Loma Marcelo skarn protoliths determined from the crystallization age of the granite that hosts the skarn and from detrital zircons of the calcic skarn, respectively. The red field indicates the $\delta^{13} \mathrm{C}$ values corresponding to the sedimentation age interval of the skarn protoliths (not the determined values; see the text for further details). (For interpretation of the references to colour in this figure legend, the reader is referred to the Web version of this article.) 
2015).

The minimum sedimentation age for both carbonate protoliths is given by the LA-ICP-MS U-Pb crystallization age of $621.6 \pm 2.2 \mathrm{Ma}$ obtained from zircons of the Loma Marcelo Granite (this work). On the other hand, the maximum sedimentation age for the calcic protolith is given by the LA-ICP-MS U-Pb upper intercept age of $648 \pm 21 \mathrm{Ma}$ obtained from a single zircon of the calcic skarn (Ballivián Justiniano et al., 2017). In consequence, sedimentation of the calcic protolith would have occurred between the Late Cryogenian (post-648 Ma) and the Early Ediacaran (pre-622 Ma).

Ballivián Justiniano et al. (2017) related the Loma Marcelo skarn protoliths to the carbonate sedimentation registered in the Neoproterozoic sedimentary cover of the Tandilia System (Villa Mónica and Loma Negra formations of the Sierras Bayas Group). This unit is unconformable deposited on the Río de la Plata Craton. However, the African lineage of the Tonian magmatism and the Ediacaran pre-collisional rocks $(<\sim 600 \mathrm{Ma})$ of the Ventania System basement and its possible correlation with the Gariep Belt (Ballivián Justiniano et al., under review), requires a revision of the source of the Loma Marcelo skarn protoliths.

The Neoproterozoic-Early Cambrian rocks of the Gariep Belt comprise two major tectonostratigraphic units known as Port Nolloth Zone (ca. 770-550 Ma) and Marmora Terrane (ca. 610-550 Ma) (Frimmel, 2018 and references therein). The sedimentary sequence of the Gariep Belt contains at least two glaciogenic diamictite units corresponding to the Sturtian (717-660 Ma) and Marinoan (650-632 Ma) glaciations (Rooney et al., 2015). Carbonate deposits follow both diamictites. Sedimentation in the Port Nolloth Zone, which comprises the Port Nolloth
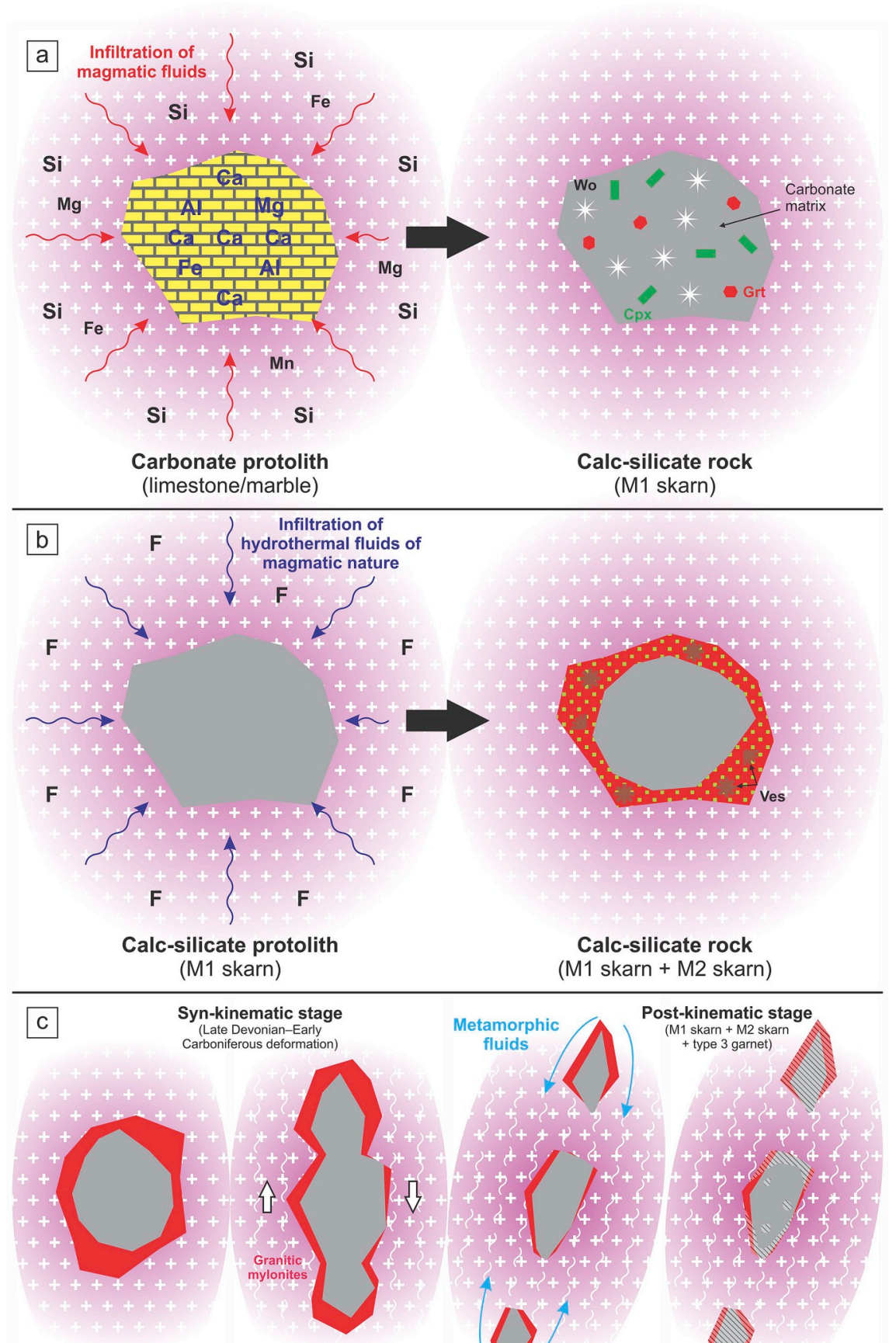

Pre-kinematic stage (M1 skarn + M2 skarn)
Fig. 16. a) Infiltration of magmatic fluids into carbonate xenoliths of sedimentary origin incorporated by the Loma Marcelo Granite during its emplacement and formation of the M1 skarn. b) Infiltration of hydrothermal fluids of magmatic nature in the M1 skarn and formation of the M2 skarn. c) From left to right: M1 skarn (grey) + M2 skarn (red) before deformation and coeval metamorphism; deformation (D1) of the Sauce Chico Inlier granites and the Loma Marcelo skarn (M1 + M2); circulation of metamorphic fluids linked to the M3-D1 event; late static crystallization of type 3 garnet. Abbreviations: $\quad \mathrm{Cpx}=$ clinopyroxene,$\quad \mathrm{Grt}=$ garnet, Ves = vesuvianite, Wo $=$ wollastonite. (For interpretation of the references to colour in this figure legend, the reader is referred to the Web version of this article.) 


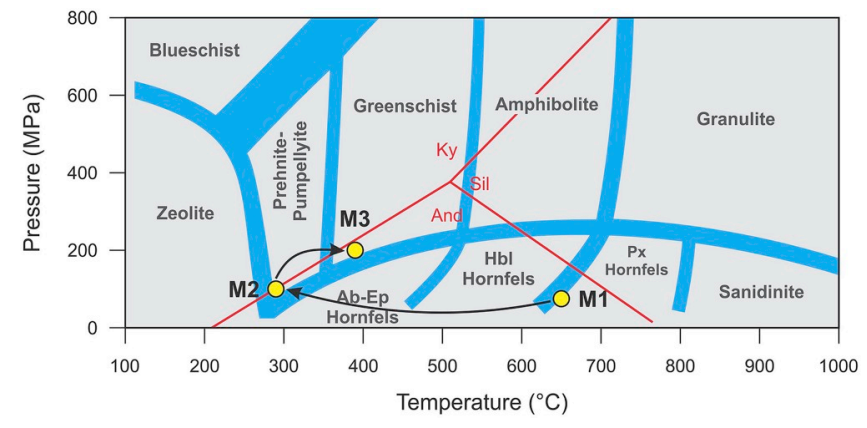

Fig. 17. Clockwise P-T path indicating the metamorphic evolution of the Loma Marcelo skarn. Abbreviations: $\mathrm{Ab}=$ albite, $\mathrm{And}=$ andalusite, $\mathrm{Ep}=$ epidote, $\mathrm{Hbl}=$ hornblende, $\mathrm{Ky}=$ kyanite, $\mathrm{Px}=$ pyroxene, $\mathrm{Sil}=$ sillimanite.

Group, is poorly constrained, however it could coincide with the waning stage of the Marinoan glaciation ( $\sim 635 \mathrm{Ma}$; Frimmel, 2018). The maximum and minimum sedimentation ages of the calcic protolith of the Loma Marcelo skarn could suggest a coeval deposition with the end of the Marinoan glaciation or after it.

\subsection{Age constraints of the skarn formation}

The first metamorphic event (M1) identified in the Loma Marcelo skarn is related to the intrusion of the Loma Marcelo Granite, so its age can be assigned to the crystallization age of the granite that hosts the skarn $(621.6 \pm 2.2 \mathrm{Ma})$.

A second metamorphic event (M2) related to the Early Cambrian alkaline plutonism of the Ventania System was also recognized in the Loma Marcelo skarn by the presence of vesuvianite and chondrodite with high-F contents. The Sm-Nd isotopic dating of cogenetic grossular with vesuvianite gave an age of $526.8 \pm 12.0 \mathrm{Ma}$ (garnet-whole rock pair isochron) and allowed the F-metasomatism to be associated with the Early Cambrian alkaline magmatism (Ballivián Justiniano et al., 2017).

Finally, the third metamorphic event (M3) identified in the Loma Marcelo skarn is related to the Ventania System deformation (D1). During the D1 event, the crystalline basement and the Palaeozoic sedimentary cover were deformed together. The first one was mylonitized and the second one was folded. Although the deformation age of the Ventania System is assigned to the Early Permian (Varela et al., 1985; Buggisch, 1987; Tomezzoli, 1999, 2001; Tomezzoli and Vilas, 1999), the existence of a previous deformational event of Late Devonian-Early Carboniferous age is not ruled out (Ballivián Justiniano et al., 2017).

\subsection{Metamorphic and tectonic evolution}

\subsubsection{First metamorphic event (M1)}

The first metamorphic event registered in the Loma Marcelo skarn was directly related with the ascent and emplacement of the Loma Marcelo Granite. The contact metamorphism and metasomatism that affected the carbonate protoliths led to the almost complete disappearance of the original mineral phases and to the formation of calcic and magnesian skarns, depending on the protolith composition. Andraditic grossular $\left(\mathrm{Grs}_{72-91 \%} \mathrm{Adr}_{4-27 \%}\right)$, diopsidic hedenbergite ( $\mathrm{Di}_{42-49 \%} \mathrm{Hd}_{50-57 \%}$ ), wollastonite, meionite, and bytownite were formed in the calcic skarn, whereas forsterite (Fo ${ }_{98-99 \%}$ ) and spinel $\left(\mathrm{Spl}_{96-97 \%}\right)$ were formed in the magnesian skarn.

Reaction of minerals of the carbonate protoliths with dissolved silica introduced by aqueous fluids, promoted the formation of new mineral phases. This is particularly evident in the magnesian skarn, where forsterite was formed from reactions that do not involve silicate minerals as reactants (e.g., tremolite, diopside), being the product of the reaction between the dolomite of the protolith and the silica metasomatically introduced. In the case of carbonate xenoliths immersed in an intrusive body, the introduction of fluids into them would have occurred centripetally through the intergranular contacts or any pre-existent structure (Fig. 16a).

The composition of calcite inclusions in forsterite from the magnesian skarn allowed a formation temperature of about $650^{\circ} \mathrm{C}$ to be calculated. This temperature is within the range of temperatures at which granitic magmas crystallize. Ballivián Justiniano (2016) pointed out that the normative composition of the Loma Marcelo Granite falls between the thermal minimums of 50 and $100 \mathrm{MPa}$ of the Q-Ab-Or- $\mathrm{H}_{2} \mathrm{O}$ system (Johannes and Holtz, 1996). These temperature and pressure conditions correspond to the pyroxene-hornfels facies of contact metamorphism (Fig. 17). During the retrograde stage, titanite would have been formed in the calcic skarn. No retrograde minerals attributable to this event were identified in the magnesian skarn.

\subsubsection{Second metamorphic event (M2)}

The second metamorphic event was linked to the heat influx and hydrothermal activity related to the Early Cambrian magmatism of the Ventania System, especially that of alkaline composition. Near the intrusive bodies, the fluid phase has a high fugacity and reaches shallow crustal levels of lower pressure and temperature. The formation of convective hydrothermal systems favoured the transfer of heat and chemical elements. The Early Cambrian alkaline magmatism was characterized by the circulation of F-rich fluids provided by the postmagmatic hydrothermal activity of alkaline granites and was responsible for the F-metasomatism evidenced in the Loma Marcelo skarn. Grossular ( $\left.\mathrm{Grs}_{85-99 \%}\right)$, hedenbergitic diopside ( $\mathrm{Di}_{63-88 \%}$ $\left.\mathrm{Hd}_{12-36 \%}\right)$, and high-F vesuvianite $\left(\mathrm{X}_{\mathrm{F}}=0.33\right)$ were formed in the calcic skarn, whereas high-F chondrodite $\left(X_{F}=0.75\right)$ were formed in the magnesian skarn.

The identification of forsterite and dolomite inside chondrodite crystals, forming coronitic textures, indicates the formation of chondrodite by replacement of the forsterite crystallized during the previous metamorphic event (chondroditization) and from the dolomite of the carbonate matrix. In the latter case, the metasomatic introduction of silica should be essential. On the other hand, petrographic evidence suggests that $\mathrm{P} 4 / \mathrm{nnc}$ space group vesuvianite was formed by replacement of the grossular-diopside-wollastonite assemblage.

The infiltration of fluids during the M1 event and the resulting reactions modified the permeability of the carbonate protoliths and supported the pervasiveness of the metasomatic alteration of the M2 event. The skarns formed during the M1 event were the protoliths during the M2 event. In the calcic skarn, the fluids did not penetrate the entire xenolith, forming a rim characterized by the assemblage garnet-clinopyroxene-vesuvianite-calcite (Fig. 16b). In the magnesian skarn, the fluids completely penetrated the rock, resulting in practically total chondroditization of the forsterite formed during the M1 event.

The Cerro Colorado and Agua Blanca alkaline granites present fluorite as a common accessory mineral and $\mathrm{F}$ contents up to $2.89 \%$ (Grecco and Gregori, 1993). Fluorine was associated with the fluoritization stage developed during the post-magmatic hydrothermal activity of the alkaline magmatism. On the basis of microthermometric studies of fluid inclusions in fluorite from the Cerro Colorado and Agua Blanca granites, Grecco and Gregori (1993) determined a temperature of $320^{\circ} \mathrm{C}$ for the fluoritization process. Likewise, on the basis of microthermometric studies of fluid inclusions in vesuvianite from the Loma Marcelo skarn, Ballivián Justiniano (2016) determined temperatures up to $283^{\circ} \mathrm{C}$ for the F-metasomatism. The normative composition of the Cerro Colorado and Agua Blanca granites falls between the thermal minimums of 100 and $200 \mathrm{MPa}$ of the Q-Ab-Or- $\mathrm{H}_{2} \mathrm{O}$ system (Johannes and Holtz, 1996), which allows a shallow intrusion to be inferred (Grecco and Gregori, 1993). Thus, the pressure of $100 \mathrm{MPa}$ is taken in this work as that corresponding for the M2 event. These temperature and pressure conditions correspond to the lower part of the prehnite-pumpellyite facies (Fig. 17). The formation of minerals typical of high temperatures (e.g., chondrodite, high-symmetry vesuvianite) at 
low temperature most likely represents natural evidence of mineral formation under disequilibrium conditions favoured by the reactivity of hydrothermal fluids.

\subsubsection{Third metamorphic event (M3)}

During the mylonitization of the basement rocks, epidotization and serpentinization took place in the calcic and magnesian skarns, respectively. The elongated shapes and discontinuous distribution of the calcic skarn bodies, parallel to the foliation of the granitic mylonites, are the result of the boudinage experienced by the calc-silicate rocks during the ductile shearing that affected the basement rocks. This is the main structural feature identified as D1 (first deformation event which is synchronous with the M3 metamorphic event). Grossular ( $\mathrm{Grs}_{95-100 \%}$ ) crystallized in the calcic skarn by static crystallization processes and is interpreted as post-tectonic in relation to D1 due to the absence of deformational features. Fig. 16c shows an approximately spherical shaped calc-silicate body being deformed by shearing, resulting in lengthening, local thinning, and boudin formation.

The maximum metamorphic degree achieved by the basement rocks of the Sauce Chico Inlier reaches the lower part of the greenschist facies (Fig. 17). The deformation mechanisms identified by Ballivián Justiniano et al. (2017) in the granitic mylonites of the Sauce Chico Inlier suggest temperatures below $400{ }^{\circ} \mathrm{C}$ during mylonitization. It is worth noting that the assemblage chlorite-epidote-actinolite was identified in the Cerro Pan de Azúcar Andesite and would indicate metamorphic temperatures of about $350-380{ }^{\circ} \mathrm{C}$ depending on pressure (Schreyer and Abraham, 1978). This assemblage occurs together with albite-oligoclase and quartz. The assemblage chlorite-epidote-actinolite-Na-plagioclase $( \pm$ quartz $)$ is indicative of greenschist facies conditions in intermediate and mafic rocks. On the other hand, Delpino and Dimieri (1992) estimated a pressure of $200 \mathrm{MPa}$ from a mineral paragenesis formed during deformation in the Cerro del Corral Granite.

\section{4. $C$ and $O$ stable isotopes in carbonates from the Loma Marcelo skarn}

The Loma Marcelo skarn carbonate minerals are depleted in ${ }^{13} \mathrm{C}$ and ${ }^{18} \mathrm{O}$ relative to $\delta^{13} \mathrm{C}$ and $\delta^{18} \mathrm{O}$ values common in marine limestones of Ediacaran-Cryogenian age. However, ${ }^{13} \mathrm{C}$ and ${ }^{18} \mathrm{O}$ depletions in carbonates from the Loma Marcelo skarn can be interpreted through the mass balance model of Taylor (1977) as resulting from fluid-rock interactions between aqueous magmatic fluids $\left(\mathrm{X}_{\mathrm{CO} 2}<0.1\right)$ and Neoproterozoic carbonate sedimentary rocks that experienced at least three metamorphic events in the temperature range between 700 and $250{ }^{\circ} \mathrm{C}$.

Isotopic similarities between the calcite sample from a vein of Cerro 21 de Septiembre and carbonates from the Loma Marcelo skarn suggest isotopic homogenization. This process can be related to the deformation (D1) and metamorphism (M3) that caused basement mylonitization, which was linked to the circulation of a great amount of fluid facilitated by the high permeability provided by the mylonitic foliation. It is notable that the calcic skarn carbonates most depleted in ${ }^{13} \mathrm{C}$ and enriched in ${ }^{18} \mathrm{O}$ are those corresponding to the ends of the aligned calc-silicate rock bodies (Fig. 18). Fluids were channelled along the shear belts, favouring the mentioned isotopic modifications due to the circulation of substantial amounts of hydrothermal fluids (possibly with an important meteoric component). The amount of interacting external fluid may be expressed in terms of the $\mathrm{W} / \mathrm{R}$ ratio. A rock with $\delta^{13} \mathrm{C}$ and $\delta^{18} \mathrm{O}$ values as observed in the Loma Marcelo skarn requires an interaction of $30 \mathrm{~cm}^{3} \mathrm{H}_{2} \mathrm{O}$ per $1 \mathrm{~cm}^{3}$ rock $(W / R=30)$, which represents a minimum value. The extremes of the deformed calc-silicate body experienced a greater interaction with fluids $(\mathrm{W} / \mathrm{R}=50)$ than the core sectors $(\mathrm{W} /$ $\mathrm{R}=30$ ). Thus, the internal portions were homogenized isotopically, whereas the rims suffered a greater depletion in ${ }^{13} \mathrm{C}$. These high water-rock ratios can explain the isotopic disequilibrium indicated by Ballivián Justiniano et al. (2017) in silicate and oxide minerals from the Loma Marcelo skarn.
Grecco et al. (2000) pointed out that mylonitization of the Ventania System basement caused mobilization of almost all major and trace elements, including REE. The mobility of elements could be related to the circulation of large amounts of aqueous fluids, as suggested by the high water-rock ratios determined from the isotopic modelling of ${ }^{13} \mathrm{C}$ and ${ }^{18} \mathrm{O}$ depletions in carbonates from the Loma Marcelo skarn. Additionally, ductile shearing observed in the crystalline basement of the Ventania System could have been favoured by the fluid activity, which contributed to an effective distribution of heat and weakening of the materials (Sellés-Martínez, 2001). The presence of ligands (e.g., F and/ or $\mathrm{Cl}$ ) and the formation of coordination complexes can also explain the mobility of elements. Fluorine and chlorine can be crucial in the transport of elements such as $\mathrm{Al}, \mathrm{Ti}, \mathrm{Zr}, \mathrm{Nb}, \mathrm{Hf}$, Ta, and REE, which are regarded as immobile under most geologic environments and processes (e.g., Tagirov et al., 2002a, 2002b; Hammerli and Rubenach, 2018 and references therein). Due to the mobility of elements, care must be taken with accuracy of pressures calculated from the normative composition of the Loma Marcelo Granite and the Early Cambrian alkaline granites.

\section{Conclusions}

Based on the available geological, mineralochemical, geochronological, and isotopic data, the following evolution of the Loma Marcelo skarn within the geotectonic context of the crystalline basement of the Ventania System is proposed:

1) During its ascent and emplacement, the Loma Marcelo Granite incorporated xenoliths of carbonate rocks of calcic and magnesian composition, forming calcic and magnesian skarns, respectively, collectively referred to as Loma Marcelo skarn.

2) The Loma Marcelo Granite has an LA-ICP-MS U-Pb crystallization age of $621.6 \pm 2.2 \mathrm{Ma}$. A previous LA-ICP-MS U-Pb upper intercept age of $648 \pm 21$ Ma determined from a single zircon of the calcic skarn provided the maximum sedimentation age for the calcic protolith. In consequence, sedimentation of the calcic protolith would have occurred between $c a .648$ and $c a$. $622 \mathrm{Ma}$.

3) The African lineage of the pre-600 Ma basement rocks of the Ventania System would allow relating the carbonate protoliths of the Loma Marcelo skarn to the Neoproterozoic carbonate sedimentation recorded in Western Africa.

4) The first metamorphic event (M1; ca. $622 \mathrm{Ma}$ ) identified in the Loma Marcelo skarn was related to the intrusion of the Loma Marcelo Granite. Reaction of minerals of the carbonate protoliths with dissolved silica introduced by aqueous fluids, promoted the formation of new mineral phases during contact metamorphism. Andraditic grossular $\left(\mathrm{Grs}_{72-91 \%} \mathrm{Adr}_{4-27 \%}\right)$, diopsidic hedenbergite ( $\mathrm{Di}_{42-49 \%} \mathrm{Hd}_{50-57 \%}$ ), wollastonite, meionite, and bytownite were formed in the calcic skarn, whereas forsterite $\left(\mathrm{Fo}_{98-99 \%}\right)$ and spinel

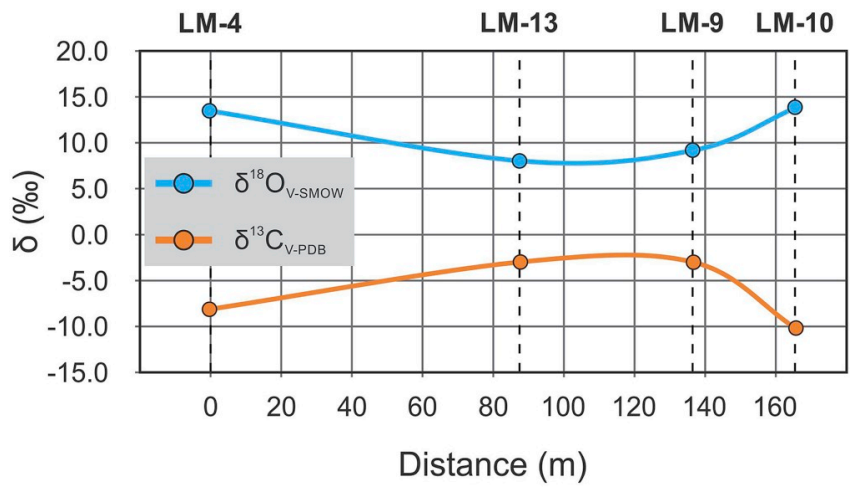

Fig. 18. $\delta^{13} \mathrm{C}$ and $\delta^{18} \mathrm{O}$ variations of the calcic skarn carbonates in function of their position in the boudinaged calc-silicate body (LM-4 = NNW end; LM$10=$ SSE end) 
$\left(\mathrm{Spl}_{96-97 \%}\right)$ were formed in the magnesian skarn. The temperature and pressure conditions estimated for the $\mathrm{M} 1$ event $\left(650^{\circ} \mathrm{C}\right.$; 50-100 MPa) correspond to the pyroxene-hornfels facies of contact metamorphism.

5) The second metamorphic event (M2; ca. $527 \mathrm{Ma}$ ) was linked to the heat influx and hydrothermal activity related to the Early Cambrian alkaline magmatism of the Ventania System. This event was characterized by the circulation of F-rich fluids provided by the postmagmatic hydrothermal activity of A-type granites and was responsible for the F-metasomatism evidenced in the skarn. Grossular $\left(\mathrm{Grs}_{85-99 \%}\right)$, hedenbergitic diopside ( $\left.\mathrm{Di}_{63-88 \%} \mathrm{Hd}_{12-36 \%}\right)$, and high- $\mathrm{F}$ vesuvianite were formed in the calcic skarn, whereas high-F chondrodite were formed in the magnesian skarn. The temperature and pressure conditions estimated for the $\mathrm{M} 2$ event $\left(<300{ }^{\circ} \mathrm{C}\right.$; $\left.100 \mathrm{MPa}\right)$ correspond to the lower part of the prehnite-pumpellyite facies.

6) Chondrodite was formed by chondroditization of forsterite (M1), whereas $\mathrm{P} 4 / \mathrm{nnc}$ space group vesuvianite was formed by replacement of the grossular-diopside-wollastonite assemblage (M1). The formation of minerals typical of high temperatures at a low temperature $\left(<300^{\circ} \mathrm{C}\right)$ most likely represents natural evidence of mineral formation under disequilibrium conditions favoured by the reactivity of hydrothermal fluids.

7) The third metamorphic event (M3) identified in the Loma Marcelo skarn was related to the basement mylonitization (D1). Regardless of the mylonitization age of the Ventania System basement, deformation and metamorphism in the Sauce Chico Inlier would have reached temperatures between 350 and $380{ }^{\circ} \mathrm{C}$ and pressures of about $200 \mathrm{MPa}$. These conditions correspond to the lower part of the greenschist facies. Epidotization and serpentinization took place in the calcic and magnesian skarns, respectively. The skarn bodies were boudinaged by the reverse dextral shearing that affected the basement rocks. Grossular $\left(\mathrm{Grs}_{95-100 \%}\right)$ crystallized posttectonically in the calcic skarn.

8) The Loma Marcelo skarn experienced a clockwise P-T path, from older high-temperature/low-pressure contact metamorphism to younger low-grade metamorphism and deformation.

9) The Loma Marcelo skarn carbonate minerals are depleted in ${ }^{13} \mathrm{C}$ and ${ }^{18} \mathrm{O}$ due to fluid-rock interactions between aqueous magmatic fluids and Neoproterozoic carbonate sedimentary rocks that experienced at least three metamorphic events in the temperature range between 700 and $250{ }^{\circ} \mathrm{C}$.

10) The high water-rock ratios, as well as the formation of coordination complexes, could help to explain the mobility of elements pointed out by other authors for the Ventania System basement.

\section{Acknowledgements}

We would like to acknowledge Agustín Martín-Izard (Universidad de Oviedo, Spain) and Fernando Colombo (Universidad Nacional de Córdoba, Argentina) for their help with the electron microprobe analysis. We also acknowledge Miguel del Blanco (Universidad Nacional de La Plata, Argentina) for his valuable help during the petrographic analysis. This study was supported by a postdoctoral research fellowship awarded to the first author by the Consejo Nacional de Investigaciones Científicas y Técnicas (CONICET) of Argentina. Research grants awarded by the Comisión de Investigaciones Científicas de la Provincia de Buenos Aires and the Universidad Nacional de La Plata (N 617, N 716, N 778, N 860) also supported this study. We warmly acknowledge the comments and suggestions of Pablo D. González, Alcides N. Sial, and Maximiliano Naipauer, which improved the original manuscript considerably.

\section{Appendix A. Supplementary data}

Supplementary data to this article can be found online at https:// doi.org/10.1016/j.jsames.2019.03.001.

\section{References}

Alessandretti, L., Philipp, R.P., Chemale Jr., F., Brückmann, M.P., Zvirtes, G., Matté, V., Ramos, V.A., 2013. Provenance, volcanic record, and tectonic setting of the paleozoic Ventania fold belt and the claromecó foreland basin: implications on sedimentation and volcanism along the southwestern gondwana margin. J. South Am. Earth Sci. 47, $12-31$.

Andreis, R.R., Iñíguez, A.M., Lluch, J.L., Rodríguez, S., 1989. Cuenca paleozoica de Ventania, sierras australes, provincia de Buenos Aires. In: Chebli, G.A., Spalletti, L.A. (Eds.), Cuencas Sedimentarias Argentinas. Instituto Superior de Correlación Geológica, Serie Correlación Geológica 6. San Miguel de Tucumán, Argentina, pp. 265-298.

Anovitz, L.M., Essene, E.J., 1987. Phase equilibria in the system $\mathrm{CaCO}_{3}-\mathrm{MgCO}_{3}-\mathrm{FeCO}_{3}$. J. Petrol. 28, 389-414.

Arem, J.E., Burnham, C.W., 1969. Structural variations in idocrase. Am. Mineral. 54, 1546-1550.

Armbruster, T., Gnos, E., 2000a. Tetrahedral vacancies and cation ordering in low-temperature Mn-bearing vesuvianites: indication of a hydrogarnet-like substitution. Am. Mineral. 85, 570-577.

Armbruster, T., Gnos, E., 2000b. 'Rod' polytypism in vesuvianite: crystal structure of a low-temperature P4nc vesuvianite with pronounced octahedral cation ordering. Schweizerische Mineralogische und Petrographische Mitteilungen 80, 109-116.

Arzadún, G., Tomezzoli, R.N., Trindade, R., Gallo, L.C., Cesaretti, N.N., Calvagno, J.M., 2018. Shrimp zircon geochronology constrains on permian pyroclastic levels, claromecó basin, South west margin of gondwana, Argentina. J. South Am. Earth Sci. 85, 191-208.

Bailey, S.W., Banfield, J.F., Barker, W.W., Katchan, G., 1995. Dozyite, a 1:1 regular interstratification of serpentine and chlorite. Am. Mineral. 80, 65-77.

Ballivián Justiniano, C.A., 2016. Geología y aspectos estructurales del área Cerro Pan de Azúcar-Cerro del Corral. Procesos petrogenéticos/geoquímica del skarn Loma Marcelo, Sierras Australes de Buenos Aires. Ph.D. thesis. Universidad Nacional de La Plata.

Ballivián Justiniano, C.A., Lanfranchini, M.E., Recio Hernández, C., de Barrio, R.E., 2015. Procesos metamórficos y metasomáticos en el skarn Loma Marcelo, basamento neoproterozoico de las Sierras Australes de la Provincia de Buenos Aires. Rev. Asoc. Geol. Argent. 72, 404-418.

Ballivián Justiniano, C.A., Lanfranchini, M.E., Recio Hernández, C., de Barrio, R.E., Sato, A.M., Basei, M.A.S., Pimentel, M.M., Etcheverry, R.O., Tassinari, C.C.G., 2017. Geology and petrogenetic considerations of the loma Marcelo skarn, neoproterozoic basement of the Ventania system, Argentina. Precambrian Res. 302, 358-380.

Basei, M.A.S., Peel, E., Sánchez Bettucci, L., Preciozzi, F., Nutman, A.P., 2011. The basement of the Punta del Este Terrane (Uruguay): an African Mesoproterozoic fragment at the eastern border of the South American Río de La Plata craton. Int. J. Earth Sci. 100, 289-304.

Basei, M.A.S., Frimmel, H.E., Campos Neto, M. da C., de Araujo, C.E.G., de Castro, N.A. Passarelli, C.R., 2018. The tectonic history of the southern Adamastor Ocean based on a correlation of the Kaoko and Dom Feliciano belts. In: Siegesmund, S., Basei, M.A.S., Oyhantçabal, P., Oriolo, S. (Eds.), Geology of Southwest Gondwana. Regional Geology Reviews, Cham, pp. 63-85.

Baumgartner, L.P., Valley, J.W., 2001. Stable isotope transport and contact metamorphic fluid flow. In: Valley, J.W., Cole, D.R. (Eds.), Stable Isotope Geochemistry. Reviews in Mineralogy and Geochemistry 43, Chantilly, pp. 415-467.

Berman, R.G., 1988. Internally-consistent thermodynamic data for minerals in the system $\mathrm{Na}_{2} \mathrm{O}-\mathrm{K}_{2} \mathrm{O}-\mathrm{CaO}-\mathrm{MgO}-\mathrm{FeO}-\mathrm{Fe}_{2} \mathrm{O}_{3}-\mathrm{Al}_{2} \mathrm{O}_{3}-\mathrm{SiO}_{2}-\mathrm{TiO}_{2}-\mathrm{H}_{2} \mathrm{O}-\mathrm{CO}_{2}$. J. Petrol. 29, 445-522.

Bowman, J.R., 1998a. Basic aspects and applications of phase equilibria in the analysis of metasomatic Ca-Mg-Al-Fe-Si skarns. In: Lentz, D.R. (Ed.), Mineralized IntrusionRelated Skarn Systems. Mineralogical Association of Canada, Short Course Volume 26, Quebec, pp. 1-49.

Bowman, J.R., 1998b. Stable-isotope systematics of skarns. In: Lentz, D.R. (Ed.), Mineralized Intrusion-Related Skarn Systems. Mineralogical Association of Canada, Short Course Volume 26, Quebec, pp. 99-145.

Bucher, K., 1998. Growth mechanisms of metasomatic reaction veins in dolomite marbles from the Bergell Alps. Mineral. Petrol. 63, 151-171.

Bucher-Nurminen, K., 1982. On the mechanism of contact metamorphic aureole formation in dolomitic country rock by the Adamello intrusion (northern Italy). Am. Mineral. 67, 1101-1117.

Bucher, K., Grapes, R., 2011. Petrogenesis of Metamorphic Rocks. Springer, Berlin.

Buggisch, W., 1987. Stratigraphy and very low-grade metamorphism of the Sierras Australes de la Provincia de Buenos Aires (Argentina) and implications in Gondwana correlation. Zentralbatt für Geologie Paläontologie, Teil I (7/8), 819-837.

Cobbold, P.R., Gapais, D., Rossello, E.A., 1991. Partitioning of transpressive motions within a sigmoidal foldbelt: the Variscan Sierras Australes, Argentina. J. Struct. Geol. $13,743-758$.

Craig, H., 1957. Isotopic standards for carbon and oxygen and correction factors for massspectrometric analysis of carbon dioxide. Geochem. Cosmochim. Acta 12, 133-149.

Cuerda, A.J., Cingolani, C.A., Barranquero, H.R., 1975. Estratigrafía del basamento precámbrico en la comarca de los cerros Pan de Azúcar-del Corral, Sierras Australes (Provincia de Buenos Aires). In: $2^{\circ}$ Congreso Iberoamericano de Geología Económica, Buenos Aires, Actas, vol. 1. pp. 57-63.

De Capitani, C., Petrakakis, K., 2010. The computation of equilibrium assemblage diagrams with Theriak/Domino software. Am. Mineral. 95, 1006-1016.

Deer, W.A., Howie, R.A., Zussman, J., 1992. An Introduction to the Rock-Forming Minerals. Wiley, New York.

Deines, P., 1989. Stable isotope variations in carbonatites. In: Bell, K. (Ed.), Carbonatites: Genesis and Evolution. Unwin Hyman, London, pp. 301-359. 
Delpino, S.H., 1993. Mecanismos de deformación y transformaciones mineralógicas como indicadores del régimen de deformación operante sobre las rocas del basamento del faldeo Occidental del cerro del Corral, Sierras Australes de Buenos Aires. In: $12^{\circ}$ Congreso Geológico Argentino y $2^{\circ}$ Congreso de Exploración de Hidrocarburos, Buenos Aires, Actas, vol. 3. pp. 21-31.

Delpino, S.H., Dimieri, L.V., 1992. Análisis de la deformación sobre las rocas del basamento aflorantes en el faldeo Occidental del cerro del Corral, Sierras Australes Bonaerenses. In: $7^{\circ}$ Reunión de Microtectónica, Bahía Blanca, Actas, pp. 53-61.

Droop, G.T.R., 1987. A general equation for estimating $\mathrm{Fe}^{3+}$ concentrations in ferromagnesian silicates and oxides from microprobe analyses, using stoichiometric criteria. Mineral. Mag. 51, 431-435.

Einaudi, M.T., Meinert, L.D., Newberry, R.J., 1981. Skarn deposits. In: In: Skinner, B.J. (Ed.), Economic Geology. 75th Anniversary Volume, Littletonpp. 317-391.

Ferry, J.M., 1986. Reaction progress: a monitor of fluid-rock interaction during metamorphic and hydrothermal events. In: Walther, J.V., Wood, B.J. (Eds.), Fluid-Rock Interactions during Metamorphism. Springer-Verlag, New York, pp. 60-88.

Ferry, J.M., Sorensen, S.S., Rumble, D., 1998. Structurally controlled fluid flow during contact metamorphism in the Ritter Range pendant, California, USA. Contrib. Mineral. Petrol. 130, 358-378.

Ferry, J.M., Ushikubo, T., Valley, J.W., 2011. formation of forsterite by silicification of dolomite during contact metamorphism. J. Petrol. 52, 1619-1640.

Ferry, J.M., Wing, B.A., Penniston-Dorland, S.C., Rumble, D., 2002. The direction of fluid flow during contact metamorphism of siliceous carbonate rocks: new data for the Monzoni and Predazzo aureoles, northern Italy, and a global review. Contrib. Mineral. Petrol. 142, 679-699.

Fitzgerald, S., Leavens, P.B., Nelen, J.A., 1992. Chemical variation in vesuvianite. Contrib. Mineral. Petrol. 46, 163-178.

Fitzgerald, S., Rheingold, A.L., Leavens, P.B., 1986. Crystal structure of a Cu-bearing vesuvianite. Am. Mineral. 71, 1011-1014.

Frimmel, H.E., 2018. The Gariep belt. In: Siegesmund, S., Basei, M.A.S., Oyhantçabal, P., Oriolo, S. (Eds.), Geology of Southwest Gondwana. Regional Geology Reviews, Cham, pp. 353-386.

Galuskin, E.V., Armbruster, T., Malsy, A., Galuskina, I.O., Sitarz, M., 2003. Morphology, composition and structure of low-temperature $\mathrm{p} 4 / \mathrm{nnc}$ high-fluorine vesuvianite whiskers from Polar Yakutia, Russia. Can. Mineral. 41, 843-856.

Gnos, E., Armbruster, T., 2006. Relationship among metamorphic grade, vesuvianite "rod polytypism" and vesuvianite composition. Am. Mineral. 91, 862-870.

González, P.D., Páez, G.N., Cervera, F.M., Iribarne, M., 2004. Texturas relícticas en las metaignimbritas neoproterozoicas del basamento del cerro del Corral, Sierras Australes de Buenos Aires. Rev. Asoc. Geol. Argent. 59, 103-112.

Grecco, L.E., Gregori, D.A., 1993. Estudio geoquímico de los intrusivos graníticos cerros Colorados y Aguas Blancas, Sierras Australes, Provincia de Buenos Aires, Argentina. In: $12^{\circ}$ Congreso Geológico Argentino y $2^{\circ}$ Congreso de Exploración de Hidrocarburos, Buenos Aires, Actas, vol. 4. pp. 81-89.

Grecco, L.E., Delpino, S.H., Gregori, D.A., Dimieri, L.V., 2000. Evaluación de la movilidad de elementos mayoritarios y traza durante la milonitización de rocas del basamento de las Sierras Australes de Buenos Aires. Rev. Asoc. Geol. Argent. 55, 352-362.

Gregori, D.A., López, V.L., Grecco, L.E., 2005. A late proterozoic-early paleozoic magmatic Cycle in sierra de la Ventana, Argentina. J. South Am. Earth Sci. 19, 155-171.

Groat, L.A., Hawthorne, F.C., Ercit, T.S., 1992. The chemistry of vesuvianite. Can. Mineral. 30, 19-48.

Hammerli, J., Rubenach, M., 2018. The role of halogens during regional and contact metamorphism. In: Harlov, D.E., Aranovich, L. (Eds.), The Role of Halogens in Terrestrial and Extraterrestrial Geochemical Processes. Springer, Springer Geochemistry, Basel, pp. 649-712.

Harrington, H.J., 1947. Explicación de las Hojas Geológicas 33m y 34m, Sierras de Curamalal y de la Ventana, Provincia de Buenos Aires, vol. 61 Dirección de Minas y Geología, Boletín, Buenos Aires.

Hochella, M.F.J., Liou, J.G., Keskinen, M.J., Kim, H.S., 1982. Synthesis and stability relations of magnesium idocrase. Econ. Geol. 77, 798-808.

Hoisch, T.D., 1985. The solid solution chemistry of vesuvianite. Contrib. Mineral. Petrol. 89, 205-214.

Holness, M.B., 1997. Fluid flow paths and mechanisms of fluid infiltration in carbonates during contact metamorphism: the Beinn an Dubhaich aureole, Skye. J. Metamorph. Geol. 15, 59-70.

Huggins, F.E., Virgo, D., Huckenholz, H.G., 1977. Titanium-containing silicate garnets. I. The distribution of $\mathrm{Al}, \mathrm{Fe}^{3+}$, and $\mathrm{Ti}^{4+}$ between octahedral and tetrahedral sites. Am. Mineral. 62, 475-490.

Jacobsen, S.B., Kaufman, A.J., 1999. The Sr, C and O isotopic evolution of Neoproterozoic seawater. Chem. Geol. 161, 37-57.

Johannes, W., Holtz, F., 1996. Petrogenesis and Experimental Petrology of Granitic Rocks. Springer, Berlin.

Jones, N.W., Ribbe, P.H., Gibbs, G.V., 1969. Crystal chemistry of the humite minerals. Am. Mineral. 54, 391-411.

Kilmurray, J.O., 1961. Petrografía de las rocas ígneas de las Sierras Australes de la Provincia de Buenos Aires. Ph.D. thesis, Universidad Nacional de La Plata.

Kilmurray, J.O., 1968a. Petrología de las rocas cataclásticas y el skarn del anticlinal del Cerro Pan de Azúcar (Partido de Saavedra, Provincia de Buenos Aires). In: $3^{\circ}$ Jornadas Geológicas Argentinas, Buenos Aires, Actas, vol. 3. pp. 217-238.

Kilmurray, J.O., 1968b. Petrología de las rocas ígneas de las Sierras Australes de la Provincia de Buenos Aires $6 \mathrm{~N}^{\circ}$ 45. Revista del Museo de La Plata, pp. 155-188.

Kilmurray, J.O., 1975. Las Sierras Australes de la Provincia de Buenos Aires. Las fases de deformación y nueva interpretación estratigráfica. Rev. Asoc. Geol. Argent. 30, 331-348.

Koester, E., Porcher, C.C., Pimentel, M.M., Fernandes, L.A.D., Vignol-Lelarge, M.L., Oliveira, L.D., Ramos, R.C., 2016. Further evidence of 777 Ma subduction-related continental arc magmatism in Eastern Dom Feliciano Belt, southern Brazil: the Chácara das Pedras Orthogneiss. J. South Am. Earth Sci. 68, 155-166.

Kuhn, B.K., Reusser, E., Powell, R., 2005. Metamorphic evolution of calc-schists in the central alps, Switzerland. Schweizerische Mineralogische und Petrographische Mitteilungen 85, 175-190.

Lenz, C., Fernandes, L.A.D., McNaughton, N.J., Porcher, C.C., Masquelin, H., 2011. U-Pb SHRIMP ages for the cerro bori orthogneisses, Dom Feliciano belt in Uruguay: evidences of a $\sim 800$ Ma magmatic and $\sim 650$ Ma metamorphic event. Precambrian Res. $185,149-163$.

Llambías, E.J., 2015. Geología de los cuerpos ígneos. Asociación Geológica Argentina, Serie B Didáctica y Complementaria $\mathrm{N}^{\circ} 32$, Buenos Aires.

López-Gamundí, O., Fildani, A., Weislogel, A., Rossello, E., 2013. The age of the Tunas Formation in the Sauce grande basin-ventana foldbelt (Argentina): implications for the permian evolution of the southwestern margin of gondwana. J. South Am. Earth Sci. 45, 250-258.

Ludwig, K.R., 2008. User's Manual for Isoplot 3.7. A Geochronological Toolkit for Microsoft Excel, vol. 4 Berkeley Geochronology Center Special Publication, Berkeley.

Manning, G., 1975. Charge-transfer processes and the origin of colour and pleochroism of some Ti-rich vesuvianites. Can. Mineral. 13, 110-116.

McCrea, J.M., 1950. On the isotopic chemistry of carbonates and a paleotemperature scale. J. Chem. Phys. 18, 849-857.

Meinert, L.D., 1992. Skarns and skarn deposits. Geosci. Can. 19, 145-162.

Meinert, L.D., Dipple, G.M., Nicolescu, S., 2005. World skarn deposits. In: In: Hedenquist, J.W., Thompson, J.F.H., Goldfarb, R.J., Richards, J.P. (Eds.), Economic Geology. 100th Anniversary Volume, Littletonpp. 299-336.

Misi, A., Kaufman, A.J., Veizer, J., Powis, K., Azmy, K., Boggiani, P.C., Gaucher, C., Teixeira, J.B.G., Sanches, A.L., Iyer, S.S.S., 2007. Chemostratigraphic correlation of neoproterozoic successions in south America. Chem. Geol. 237, 143-167.

Müller, T., Baumgartner, L.P., Foster Jr., C.T., Vennemann, T.W., 2004. Metastable prograde mineral reactions in contact aureoles. Geology 32, 821-824.

Nakano, T., Takahara, H., Nishida, N., 1989. Intracrystalline distribution of major elements in zoned garnet from skarn in the Chichibu Mine, central Japan: illustration by color-coded maps. Can. Mineral. 27, 499-507.

Ohkawa, M., Yoshiasa, A., Takeno, S., 1994. Structural investigation of high- and lowsymmetry vesuvianite. Mineral. J. 17, 1-20.

Oterdoom, W.H., Wenk, H.R., 1983. Ordering and composition of scapolite: field observations and structural implications. Contrib. Mineral. Petrol. 83, 330-341.

Pan, Y., 1998. Scapolite in skarn deposits: petrogenetic and geochemical significance. In: In: Lentz, D.R. (Ed.), Mineralized Intrusion-Related Skarn Systems. Mineralogical Association of Canada, Short Course Volume 26, Quebecpp. 126-209.

Piazolo, S., Markl, G., 1999. Humite- and scapolite-bearing assemblages in marbles and calcsilicates of Dronning Maud Land, Antarctica: new data for Gondwana reconstructions. J. Metamorph. Geol. 17, 91-107.

Ramos, V.A., Chemale Jr., F., Naipauer, M., Pazos, P.J., 2014. A provenance study of the paleozoic Ventania system (Argentina): transient complex sources from western and eastern gondwana. Gondwana Res. 26, 719-740.

Rapela, C.W., Pankhurst, R.J., Fanning, C.M., Grecco, L.E., 2003. Basement evolution of the Sierra de la Ventana Fold Belt: new evidence for Cambrian continental rifting along the southern margin of Gondwana. J. Geol. Soc. 160, 613-628.

Rice, J.M., 1980a. Phase equilibria involving humite minerals in impure dolomitic limestones. Part II. Calculated stability of chondrodite and norbergite. Contrib. Mineral. Petrol. 75, 205-223.

Rice, J.M., 1980b. Phase equilibria involving humite minerals in impure dolomitic limestones: Part I. Calculated stability of clinohumite. Contrib. Mineral. Petrol. 71, 219-235.

Rice, J.M., 1983. Metamorphism of rodingites: Part I. Phase relations in a portion of the system CaO-MgO- $\mathrm{Al}_{2} \mathrm{O}_{3}-\mathrm{SiO}_{2}-\mathrm{CO}_{2}-\mathrm{H}_{2} \mathrm{O}$. Am. J. Sci. 283-A, 121-150.

Rooney, A.D., Strauss, J.V., Brandon, A.D., Macdonald, F.A., 2015. A Cryogenian chronology: two long-lasting synchronous Neoproterozoic glaciations. Geology 43 459-462.

Sato, K., Basei, M.A.S., Ferreira, C.M., Vlach, S.R.F., Ivanuch, W., Siga Jr., O., Onoe, A.T., 2010. In situ U-Th isotopic analyses by excimer laser ablation/ICP-MS on Brazilian megacrystal xenotime: first results of U-Pb isotopes at CPGeo-IG-USP. In: $7^{\circ}$ South American Symposium on Isotope Geology, Brasília, CD-ROM, pp. 349-352.

Schreyer, W., Abraham, K., 1978. Prehnite/chlorite and actinolite/epidote bearing mineral assemblages in the metamorphic igneous rocks of La Helle and Challes, VennStavelot-Massif, Belgium. Ann. Soc. Geol. Belg. 101, 227-241.

Schiller, W., 1930. Investigaciones geológicas en las montañas del sudoeste de la provincia de Buenos Aires. Anales del Museo de La Plata 4, 2-101.

Sellés-Martínez, J., 2001. Geología de la Ventania (provincia de Buenos Aires (Argentina). J. Iber. Geol. 27, 43-69.

Shannon, R.D., Prewitt, C.T., 1969. Effective ionic radii in oxides and fluorides. Acta Crystallogr. B25, 925-946.

Shimazaki, H., Shimizu, M., Nakano, T., 1986. Carbon and oxygen isotopes of calcites from Japanese skarn deposits. Geochem. J. 20, 297-310.

Tagirov, B., Schott, J., Harrichoury, J.-C., 2002a. Experimental study of aluminumfluoride complexation in near-neutral and alkaline solutions to $300{ }^{\circ} \mathrm{C}$. Chem. Geol. 184, 301-310.

Tagirov, B., Schott, J., Harrichoury, J.-C., Salvi, S., 2002b. Experimental study of aluminum speciation in fluoride-rich supercritical fluids. Geochem. Cosmochim. Acta 66, 2013-2024.

Taylor, H.P., 1977. Water/rock interactions and the origin of $\mathrm{H}_{2} \mathrm{O}$ in granitic batholiths. J. Geol. Soc. 133, 509-558.

Tohver, E., Cawood, P.A., Rossello, E.A., Jourdan, F., 2012. Closure of the clymene Ocean and formation of west gondwana in the cambrian: evidence from the sierras australes of the southernmost rio de la Plata craton, Argentina. Gondwana Res. 21, 394-405. 
Tohver, E., Cawood, P.A., Rossello, E., López de Luchi, M.G., Rapalini, A., Jourdan, F., 2008. New SHRIMP U-Pb and ${ }^{40} \mathrm{Ar} /{ }^{39} \mathrm{Ar}$ constraints on the crustal stabilization of southern South America, from the margin of the Rio de Plata (Sierra de Ventana) craton to northern Patagonia. In: American Geophysical Union, Fall Meeting 2008, abstract \#T23C-2052.

Tomezzoli, R.N., 1999. La Formación Tunas en las Sierras Australes de la Provincia de Buenos Aires. Relación entre sedimentación y deformación a través de su estudio paleomagnético. Rev. Asoc. Geol. Argent. 54, 220-228.

Tomezzoli, R.N., 2001. Further palaeomagnetic results from the Sierras Australes fold and thrust belt, Argentina. Geophys. J. Int. 147, 356-366.

Tomezzoli, R.N., Vilas, J.F., 1999. Paleomagnetic constraints on age of deformation of the Sierras Australes thrust and fold belt, Argentina. Geophys. J. Int. 138, 857-870.

Tomezzoli, R.N., Cristallini, E.O., 1998. Nuevas evidencias sobre la importancia del fallamiento en la estructura de las Sierras Australes de la Provincia de Buenos Aires. Rev. Asoc. Geol. Argent. 53, 117-129.

Tomezzoli, R.N., Cristallini, E.O., 2004. Secciones estructurales de las Sierras Australes de la provincia de Buenos Aires: repetición de la secuencia estratigráfica a partir de fallas inversas? Rev. Asoc. Geol. Argent. 59, 330-340.

Trommsdorff, V., 1968. Mineralreaktionen mit Wollastonit und Vesuvian in einem Kalksilikatfels der alpinen Disthenzone (Claro, Tessin). Schweizerische Mineralogische und Petrographische Mitteilungen 48, 655-666.

Valley, J.W., 1986. Stable isotope geochemistry of metamorphic rocks. Rev. Mineral. Geochem. 16, 445-489.

Valley, J.W., Peacor, D.R., Bowman, J.R., Essene, E.J., Allard, M.J., 1985. Crystal chemistry of a $\mathrm{Mg}$-vesuvianite and implications of phase equilibria in the system $\mathrm{CaO}$ $\mathrm{MgO}-\mathrm{Al}_{2} \mathrm{O}_{3}-\mathrm{SiO}_{2}-\mathrm{H}_{2} \mathrm{O}-\mathrm{CO}_{2}$. J. Metamorph. Geol. 3, 137-153.

Varela, R., Cingolani, C.A., 1976. Nuevas edades radimétricas del basamento aflorante en el Perfil del Cerro Pan de Azúcar-Cerro del Corral y consideraciones sobre la evolución geocronológica de las rocas ígneas de las Sierras Australes, Provincia de Buenos Aires. In: $6^{\circ}$ Congreso Geológico Argentino, Buenos Aires, Actas, vol. 1. pp. 543-556.

Varela, R., Cingolani, C., Dalla Salda, L.H., 1990. Edad del granito Cerro Colorado y su implicancia geotectónica. Sierras Australes de Buenos Aires. In: $11^{\circ}$ Congreso Geológico Argentino, Buenos Aires, Actas, vol. 2. pp. 279-282.

Varela, R., Dalla Salda, L.H., Cingolani, C.A., 1985. Estructura y composición geológica de las sierras Colorada, Chasicó y Cortapie, Sierras Australes de Buenos Aires. Rev. Asoc. Geol. Argent. 40, 254-261.

von Gosen, W., Buggisch, W., Dimieri, L.V., 1990. Structural and metamorphic evolution of the sierras australes (Buenos Aires Province/Argentina). Geol. Rundsch. 79, 797-821.

von Gosen, W., Buggisch, W., Krumm, S., 1991. Metamorphism and deformation mechanisms in the sierras australes fold and thrust belt (Buenos Aires Province, Argentina). Tectonophysics 185, 335-356.

Whitney, D.L., Evans, B.W., 2010. Abbreviations for names of rock-forming minerals. Am. Mineral. 95, 185-187.

Zharikov, V., Pertsev, N., Rusinov, V., Callegari, E., Fettes, D., 2011. Metasomatism and metasomatic rocks. In: Fettes, D., Desmons, J. (Eds.), Metamorphic Rocks: A

Classification and Glossary of Terms. Recommendations of the International Union of Geological Sciences Subcommission on the Systematics of Metamorphic Rocks, New York, pp. 58-68.

Zheng, Y.-F., 1993. Calculation of oxygen isotope fractionation in anhydrous silicate minerals. Geochem. Cosmochim. Acta 57, 1079-1091.

Zheng, Y.-F., 1999. Oxygen isotope fractionation in carbonate and sulfate minerals. Geochem. J. 33, 109-126. 